\title{
The Reinvention of Vouchers for a Color-Blind Era:
}

\section{A Racial Orders Account.}

\author{
Ursula Hackett (Royal Holloway, London) and Desmond King (Oxford). \\ Forthcoming, Studies in American Political Development.
}

\begin{abstract}
Historically vouchers, which provide a sum of money to parents for private education, were tools of racist oppression; but in recent decades some advocates claim them as 'the civil rights issue of our time.' This paper brings an analytic-historical perspective rooted in racial orders to understand how education vouchers have been reincarnated and reinvented since the Jim Crow era.

Combining original primary research with statistical analysis we identify multiple concurrent and consecutive transformations in voucher politics in three arenas of racial policy alliance contestation: expansion of color-blind policy designs, growing legal and political support from a conservative alliance, and a smorgasbord of voucher rationales rooted in color-blind framing. This approach demonstrates that education vouchers have never been racially neutral but served key roles in respect to prevailing racial hierarchies and contests.
\end{abstract}


The renaissance of education vouchers in America is indisputable and striking (Figure 1). ${ }^{i}$ While modern proponents of education vouchers cite numerous motives, the majority are at pains to promote them as ‘color-blind' or 'race neutral’ measures, to use King and Smith’s (2011, 2014) language. Color-blind advocates of vouchers claim the race of the children participating is irrelevant to the policy even though it is an activist program nominally targeting the educationally disadvantaged (Levitz 2017). In contrast, proponents of an active federal role to ameliorate enduring racial inequalities rarely advocate education vouchers, concluding that they are commonly designed by white Republican Party lawmakers and used by white parents to perpetuate de facto segregated education amongst American children (Ford, Johnson, and Partelow 2017).

The contemporary debate about education vouchers has unmissable historical echoes reflecting first the origin of voucher schemes in the 1950s when they were used as instruments to maintain racial segregation, and second their redesign after the 1960s, principally by opponents of racial progress, to accommodate the civil rights era. This paper brings an analytic-historical perspective rooted in racial orders to understand how education vouchers have been reincarnated and reinvented since Milton Friedman first formalized the idea in 1955 (Friedman 1955).

\section{[FIGURE 1 ABOUT HERE]}

We argue that the politics of such schemes - variously called tuition grants, tax credit scholarships, educational savings accounts or vouchers - is related to the dominant racial order at each historical juncture in American politics. Vouchers buttressed white supremacy during public school desegregation by funding segregated private schools. They were opposed by civil rights organizations but attracted some advocates for racial equality during the 1990s as a remedy for educational inequalities. But during President Obama’s first term vouchers became firmly 
associated with the modern color-blind alliance, consisting of Republicans and conservatives who disclaim the use of racial categories in policymaking. Our approach enables us to demonstrate that education vouchers have never been racially neutral but served key roles in respect to these prevailing racial hierarchies. ${ }^{\mathrm{ii}}$

In the era of segregated education in the decades up to 1964, vouchers emerged as an instrument developed by white supremacists to maintain that racial order as it was under threat from court orders and federal actions. Responding to the Brown (1954) decision ordering school desegregation, school districts offered tuition grants to white parents to remove their white children from public schools which had been ordered to integrate. ${ }^{\text {iii }}$ Tuition grant vouchers funded segregated institutions indirectly - channeling money via parents rather than directly to the school - in an effort to avoid legal challenge, but activists and judges exposed their racist purposes. In the 1960s and 1970s as civil and voting rights legislation transformed the segregationist order into a new civil rights regime, so proponents of racial equality worked to end the use of tuition grants in the South. More generally they opposed the use of voucher type schemes since these included the potential racially to discriminate between children.

Some liberal academics and progressive policymakers supported vouchers or tax credit voucher programs for the educationally disadvantaged, but growing racial and ideological polarization from the 1980s pushed vouchers firmly into conservatives’ issue preferences (Forman 2004). In the post-civil rights era embedded from the 1980s, American voters’ partisan and ideological polarization (McCarty, Poole, and Rosenthal 2016) has increasingly overlapped with a racial division between conservative color-blind and liberal race-conscious policy alliances: loose configurations of individuals and groups seeking to disclaim or deploy racial categories in policymaking, respectively (D. King and Smith 2011, 2014). This polarized context provides an opportunity for politicians associated with the conservative color-blind alliance to promote 
voucher type schemes which in practice contribute to keeping schools segregated (Katz and Turner 2001; Persson 2015; Reardon and Yun 2002).

Modern vouchers have some race-conscious supporters - liberals and Democrats committed to the use of racial categories in policymaking - but their support base is overwhelmingly colorblind. Since the 1990s, some of these color-blind advocates of vouchers have maintained that such schemes will be beneficial to African-American children and parents, but most are anxious to deny that vouchers result in race targeted effects. Proponents lobbied states to hold referenda to enact them. The overwhelming rejection of the schemes after such referenda prompted a strategic shift amongst voucher advocates to enact schemes in GOP controlled state legislatures. To make sense of this complexity in the evolution of voucher politics over time we draw on King and Smith’s racial policy alliances framework to distinguish three arenas in which alliances contest: rhetoric, patterns of support, and policy design (Table 1). Table 1 defines the terms 'color-blind' and 'race-conscious' for policy framing, design and support (columns 1 and 2), and situates the components of the King-Smith analytical framework in context (column 3).

\section{[TABLE 1 ABOUT HERE]}

King and Smith’s two racial policy alliances represent broad alignments rather than precise specifications of tight coalition partners. In this paper we show how the framework can be calibrated and applied in an analytic-historical way to the development of school vouchers as these schemes move through their shifting incarnations. We argue that these arenas of racial policy alliance contestation - rhetoric, patterns of support and policy design - are analytically separable, which means that race-conscious policy alliance members do not always espouse raceconscious arguments and race-conscious policy designs may be publicly justified in a color-blind 
fashion. In King and Smith’s book Still a House Divided race-consciousness and color-blindness identifies frames, policies and people as illustrated in Table 1, column 3.

For King and Smith color-blindness and race-consciousness manifests in the framing of racial issues and in parties’ professed commitments, whereby elites rhetorically emphasize or diminish racial categories (Table 1, row 1). Color-blindness and race-consciousness also occurs in the design and implementation of policy (Table 1, row 2). And race-conscious proponents and color-blind advocates form two sides of opposed racial policy alliances (Table 1, row 3). Distinguishing these three arenas of racial policy alliance conflict enables us to identify multiple concurrent and consecutive transformations in voucher politics over time.

The tenacity of racial hierarchies in US politics and the struggles to defend or reform approaches to racial equality is exceptionally well illustrated in the trajectory of education vouchers since their introduction by states in the 1950s to their contemporary embrace by Republican state governors and legislators. Our account of vouchers gives a micro example of the broad contours sketched out in the racial policy alliances framework showing the powerful ways in which institutionally embedded hierarchies operate locally to maintain and retain racist legacies (Lieberman 1997; Anderson 2016).

\section{Vouchers and racial epochs}

In this paper we use a racial orders framework to analyze how the politics of education vouchers has developed since Brown and what has driven that change. Empirically, we draw upon modern and historical newspaper sources (1953-2017), judicial rulings, civil rights reports and census data to construct an analytic narrative showing how voucher programs served the interests of those either opposing or on rare occasions promoting egalitarian racial reform rooted in America's shifting post-Civil War racial orders. We also construct two original databases, legislator votes on 
voucher bills (2005-2017) and judicial votes in voucher cases (1955-2017), to express these patterns statistically.

Our approach utilizes state legislature websites to extract information about the 6,693 legislative votes on forty-seven voucher bills passed between 2005 and 2017. In order to address possible selection bias we incorporate twelve voucher bills that were brought to a vote before July 2017 but failed to become law because they were vetoed or voted down, yielding a total of 7,851 state legislator votes. Additionally, drawing upon the universe of judicial votes in 46 voucher cases (1955-2017), and 236 individual votes, we examine the legal vulnerability of voucher programs by recording each judge's decision about the constitutionality of the program at issue.

In this paper we make four key empirical and theoretical contributions. First, we unearth patterns of tuition voucher distribution across the Jim Crow South. To our knowledge, no existing account has calculated the number and distribution of tuition grant vouchers over time for multiple states. Secondly, we advance empirically the accounts of voucher politics articulated in the first decade of the twenty-first century by analyzing the rapid increase in voucher programs after 2010 and drawing upon original datasets. Thirdly, we apply the racial orders framework developed by Desmond King and Rogers Smith to the elite politics of vouchers. Fourthly, our micro-empirical approach disaggregates the racial orders framework for the first time into its underlying dimensions design, framing, and patterns of support - in order to understand how racial orders coalesce and fragment in different eras of contestation.

The first section of this paper explains how vouchers originated in the 1950s as part of white supremacists’ struggle to resist desegregation. Such efforts were cited as empirical examples by the University of Chicago economist Milton Friedman as he articulated the theoretical rationale for vouchers (Friedman 1955).

During the momentous transition from the segregationist to the civil rights era achieved partly in laws passed by Congress in the 1960s, vouchers rarely featured in policy debates as a 
desirable method to address racial inequality in American schools. Instead the focus for getting change and reform was the combination of federal funds, adroitly granted or withheld to the states by the US Department of Education, and of court orders.

In the third section we show that as the civil rights reforms of the 1960s settled into the new alliances and struggles of the 1970s and 1980s, so opponents of federal-backed racial equality revived and redesigned school vouchers for the modern era to block reform. Table 2 illustrates the forms of racial policy alliance contestation in patterns of support, rhetoric, and policy design during the three eras of voucher politics: Jim Crow and the aftermath of Brown (1950-64); the Era of Transition (1964-96); and the Civil Rights Era and Rise of Color-Blind Vouchers (1996-). The analysis in the paper is organized around these three eras and shifts between them.

\section{[TABLE 2 ABOUT HERE]}

Expanding upon King and Smith’s racial orders framework, we show how the reinvention of vouchers took place in three key arenas of racial policy alliance contestation summarized in Table 2: patterns of support; framing and rhetoric; and design and targets. Tracing the temporality of voucher politics reveals a trend toward color-blindness punctuated by sporadic race-conscious rationales and coalition-building. ${ }^{\text {iv }}$ The revival of racial divides in contemporary voucher use is an empirical surprise but consistent with the deep legacies of racism in America identified by King and Smith and others (Brandwein 2011; Chen 2009; Harris 2012; Hochschild 1996; Francis 2014; Mazumder 2018; Mickey 2015; Murakawa 2014; Thurston 2015; Lowndes, Novkov, and Warren 2008; Gillion 2016), and mobilized in recent electoral politics (Bobo 2017; Coates 2017; Tesler 2016).

The racial orders framework guides the empirical analysis by providing explanations for the varying political purpose of vouchers at different historical stages. The use of vouchers took place in three distinct waves corresponding to the King-Smith racial orders and eras of racial 
policy alliance contestation: as part of the pro-segregationist anti-Brown resistance, during the brief race-conscious response to urban school crises, and in the explosion of color-blind vouchers paralleling the Obama presidency (D. King and Smith 2005; Johnson 2011, 2016).

Within each era we show how color-blind and race-conscious forces sought to make and unmake racial hierarchies by building coalitions, re-framing public debate and crafting policy. This periodization is close to the King and Smith (2011) framework. But our micro empirical focus enables us to expand their account of the post-1970s decades by delineating the distinct bases of support found among some race-conscious advocates versus the overwhelming colorblind mobilization base for vouchers. These nuances have been missed in many existing broad stroke accounts of changes in racial politics since the 1960s.

There are competing accounts about vouchers. The most compelling is religious activism, from which we distinguish our analysis. Although most vouchers are used at religious schools and many religious elites support vouchers, we find explanations rooted in racial policy alliances more analytically compelling for three reasons. First, religious leaders have historically played a weak or ambivalent role in the formation of voucher coalitions, ranging from reluctant Midwest Catholic dioceses to outright hostility from Texan Baptist groups (Hackett 2016). As we show in Part 2 of this paper, voucher activism in the 1990s was propelled by coalitions organized around racial justice with Catholic organizations in a supporting role. Racial policy alliances - rather than culture war categories - can more usefully describe the patterns of support of individuals and groups advocating for and against vouchers.

Secondly, the movement from 'values' arguments to racial justice claims through to ‘color-blind' framing of vouchers, mark significant shifts in vouchers' evolution (Forman 2007). Race-conscious and color-blind frames are meaningful in judicial decision-making. The Establishment Clause of the First Amendment restricts arguments for vouchers couched in terms of benefits for religious individuals or institutions, but not those framed in terms of racial justice, 
individual choice or school quality. Thirdly, voucher policies have been designed explicitly to accomplish racial goals, having their genesis in and responses to the Brown v Board decision. As we show in Part 1 of this paper, tuition grant legislation in the Jim Crow era explicitly excluded sectarian schools from participation. We do not deny the importance of religion in propelling voucher activism on occasion but find evidentially that racial policy alliances is a more compelling explanation for vouchers' patterns of support, rhetoric, and policy design and how they change over time.

\section{$\underline{\text { Part 1. Vouchers and Segregationist America }}$}

Origins and number of vouchers

The first school voucher programs were adopted in the South in response to Brown v Board of Education (1954) ${ }^{\mathrm{v}}$ (Ladson-Billings 2004; Harter and Hoffman 1973). ${ }^{\mathrm{vi}}$ Their purpose was defined by ardent defenders of the segregationist racial order. These programs were designed to enable white families to escape any desegregation of the public schooling system by utilizing publicly-funded vouchers distributed by all-white school districts to send their children to private de facto segregated academies (Ford, Johnson, and Partelow 2017). This tactic was embraced to maintain the South’s system of white supremacy (Schickler and Rubin 2016).

The laws authorized public funding for grant payments to parents to spend on private education for their children. Seven southern states passed tuition grant laws: Alabama (1955), Georgia (1953 $\left.{ }^{\mathrm{vii}}\right)$, Louisiana (1958 $\left.{ }^{\mathrm{viii}}\right)$, Mississippi (1964), North Carolina (1956), South Carolina (1963) and Virginia $\left(1956^{\mathrm{ix}}\right)$. For these states, buttressing separate schools was a pivotal component of segregation. In an eighth state, Arkansas, a publicly-funded tuition grant bill was introduced but never reached the governor's desk. Instead policymakers successfully solicited private funding for tuition grants (Special to the New York Times 1959, 1961). 
The tuition grant programs were to be used for 'segregation academies,' single-race private schools, established in direct response to Brown. Catholic or 'sectarian' schools were excluded from these tuition grant programs, partly due to anti-Catholicism in the South and partly to the fear that Catholic schools would soon start to desegregate (as, indeed, they did in many parts of the South during the early 1960s) (Carl 2011; Special to the New York Times 1964).

Compiling data on the number of grants issued during this period is challenging because official records are incomplete and inadequate. We triangulate between contemporary newspaper sources, judicial rulings and reports of the United States Commission on Civil Rights in order to piece together - for the first time - the trajectory of grant issuance across states.

Of the tuition-grant states Louisiana and Virginia distributed the largest number of grants. In its first year of operation Louisiana issued 535 tuition grants but the number quickly rose to 7,093 in its second year (1962-63) and to 11,000 the following year (Hannah et al. 1964; Wisdom 1968; McBee 1963). In 1966, the number of grants peaked at 15,177, followed by 14,059 in 1967-68, after which the program was struck down by a federal district court (Wisdom 1968).

The value of the grants was initially set at \$1.67 per day and later raised to \$2 per day, or $\$ 360$ for an assumed school year of 180 days, which was typically sufficient to cover all or most of private school fees (Wisdom 1968). We utilize data appendices attached to the Poindexter $v$ Louisiana Financial Assistance Commission case (1968) to calculate the average tuition charge in private schools set up in Louisiana after the Brown decision: \$414 per annum. ${ }^{\mathrm{x}}$ Hence the grants covered, on average, $87 \%$ of fees. Judges in many states noted that tuition grants were calibrated to the level of school fees, and vice versa (Wisdom 1968, 1961; Rives, Grooms, and Johnson 1964). Many segregated schools set up after Brown, such as Carrollton Private School, Mirabeau Elementary School, United Elementary School, and Jefferson Academy, charged precisely the cost of the tuition grant. 
These vouchers were used almost exclusively by whites although a small number of black students did use tuition grants to attend segregated academies (Godbold, Cox, and Russell 1969). In Coffey v State Education Finance Commission (1969) the vigilant judges provided a detailed data appendix on patterns of voucher usage to justify their conclusion that Mississippian tuition grants were unconstitutional. ${ }^{\mathrm{xi}}$ The Court found that all but one of the private schools receiving the $\$ 240$ tuition grant payments in the school year 1967-8 had an all-white attendance (the other school was entirely African-American) (Godbold, Cox, and Russell 1969).

In Virginia the state dispensed 4,750 grants in the school year beginning in 1959 at a cost of just over \$1 million (Carper 1960b), each grant amounting to \$125 per child for elementary students and \$150 for high-schoolers, supplemented by local sources (Black 1964; Butzner 1964). In subsequent years the number of tuition grants rose to 6,100 , then $7,261,8,518^{x i i}$, and 9,489 in 1963-64 (Associated Press 1963, 1961b, 1961a, 1960; Baker 1962; Knoll 1960; Carper 1960a; Muse 1964, 186). By 1964, Virginia had spent more than $\$ 7$ million on tuition grant payments. Even after the passage of the 1964 Civil Rights Act and a 1965 Supreme Court decision striking down the Prince Edward County’s policy of shuttering the public school system to avoid desegregation, Virginia continued to fund private tuition grants (Black 1964).

Numbers rose to 12,253 in 1964, dipping slightly to 11,983 in 1965 then climbing again to 12,786 in 1966 and almost 14,000 in 1967. Despite declining enthusiasm for the program on the part of some whiter Virginian counties towards the end of the decade, particularly Roanoke, Arlington and Alexandria, the number of tuition grants issued in 1968 (after which they were struck down by a three-judge federal court) was in excess of 13,000 (Associated Press 1969). Over the course of a decade Virginia spent nearly \$20 million in tuition grants.

By contrast, the Georgia tuition grant program’s early promise - the state spent \$1.4 million in 1961-2 alone - was quickly snuffed out after the legislature adopted additional regulations. 'The legislature provided [in 1963] that local school systems must participate in the costs and 
certify the students for private school grants, an action that virtually killed the plan' (Special to the New York Times 1967). State outlay for the grants dropped to a mere \$112,000 in 1963 and came to a halt the following year without the need for court action (Wearne 2013). Figure 2 displays the rise and fall of tuition grant payments in Virginia, Louisiana and Georgia, normalized for the size of the 5-14 year old population in each state (source: US Census data 1960). As Figure 2 shows, at their peak around 2\% of the school-age population in Louisiana and Virginia utilized tuition grants. But the impact of these grants was felt across the South.

\section{[FIGURE 2 ABOUT HERE]}

\section{Patterns of support for vouchers in defense of Jim Crow}

White supremacist Democratic governors including George and Lurleen Wallace of Alabama, Eugene Talmadge and Ernest Vandiver Jr. of Georgia, Earl Long and James Davis of Louisiana, Paul Johnson of Mississippi and Thomas B Stanley of Virginia, were vociferous supporters of tuition grant vouchers (Catsam 2009; Kruse 2005). They and their legislative allies established commissions to devise strategies to avoid desegregation. The Sibley Commission in Georgia ('the Committee on Schools of the Georgia General Assembly'), the Pearsall Committee in North Carolina, and the Gray Commission in Virginia recommended tuition grants as part of packages of measures designed to thwart desegregation (Chin et al. 2006).

Committee memberships were almost exclusively white and male - three AfricanAmericans sat on the sixteen-member Pearsall Committee in North Carolina but the Gray Commission in Virginia was drawn from the state legislature, which had no African-Americans and only one woman serving in it (Bonastia 2012, 56). Members of the Gray Commission were drawn disproportionately from south Virginian legislative districts with smaller populations but 
larger concentrations of black residents, a pattern of support that would be repeated when it came to voting on tuition grant packages across the South.

White segregationists shepherded tuition grant legislation through state legislatures. The bills did not garner uniform support. Some votes were close. But closeness reflected not principled objection to the racist ends of the measures but doubt about their efficacy in achieving widely-shared segregationist goals. Virginia’s 1956 tuition grant law passed the upper house by just four votes. There were legislators willing to speak out against tuition grants - but for prosegregationist reasons, such as expressing their fear that the 'massive resistance' approach would make federal court challenge more likely. For example, Senator Bob Wilson of Walker County, Alabama, argued that federal courts would force private schools to accept black students as long as white pupils received state aid (Associated Press 1965b). Revealingly, support for tuition grants was concentrated amongst members with the largest proportion of black residents in their districts. These were the districts that would feel the impact of desegregation most keenly (Bonastia 2012, 73; Muse 1961; Catsam 2009, 136).

\section{Tuition grant rhetoric: veneer of color-blindness}

The earliest segregation tuition grant efforts employed notionally color-blind arguments about 'freedom of choice' and 'freedom of association'. Mindful of the risk of judicial challenges, politicians publicly justified their tuition grant policies without recourse to race. In Alabama, for instance, the tuition grant law made no mention of race or color, providing that children could qualify for grants if, in the judgment of their parents, it would be detrimental to their 'physical or emotional health’ or subject them to 'hazards to personal safety’ if they attended public school. (Associated Press 1965a). These supposedly race-neutral frames formed part of a broader 'freedom of choice' response to desegregation, purportedly allowing black children to transfer to white schools but in practice subjecting would-be transfer students to harassment or intimidation 
and rejecting their applications on notionally race-neutral grounds. This language fits with the racial orders framework.

Some policymakers changed the designation of the vouchers to help minimize the association between racist purposes and state action. Virginia for example relabeled its tuition grants 'scholarships’ in 1959 and Mississippi christened its grants 'loans' a decade later (Bonastia 2012, 96; Bolton 2005, 175; Muse 1961, 134). In Virginia’s Prince Edward County, local segregationists closed the public school system for five years rather than submit to desegregation. Officials justified public funding of tuition grants for students at the whites-only Prince Edward Academy in terms of opaque 'patriotic constitutionalism' rather than full blown 'diehard segregation’. In this view, it was merely black parents’ irksome rejection of tuition grants for African-American private schools that prevented black children in the county from receiving an education. This perverse logic exposes the segregationist intent of tuition grants beneath the superficial color-blind framing.

The thread between segregation and the modern era is palpable as we show below. The sociologist Chris Bonastia makes this link too: 'In their views that tax money primarily should benefit the largest taxpayers, that government should fund private school education, and that segregation could be justified in non-racial terms, Prince Edward whites anticipated the “colorblind”, conservative strain of rhetoric that gained currency in the late 1960s and the 1970s, and that continues to strive' (Bonastia 2012, 7-8). The racialized nature of the rights of taxpayers over how funds are spent persisted in America’s racial orders (Connolly 2014; Gilens 1996).

Even in states such as Arkansas and North Carolina that passed but did not distribute tuition grants, the passage of tuition grant legislation had powerful symbolic functions for segregationist elites. It rallied supporters, roused segregationists, and placated fears of federal takeovers. In Arkansas, Governor Orville Faubus - famous for refusing to protect black children at Little Rock in 1957 - deployed the individualized rhetoric of color-blindness to express confidence that his 
tuition grants proposal would not be overturned by the courts: 'It is just carrying a little bit further the rights of an individual. All students have constitutional rights - not just members of one race or group, although the present Supreme Court seems interested in only one race' (Special to the New York Times 1959). Grants were justified on the grounds of 'individual liberty' of association for parents and students (Carl 2011, 29).

Despite this homage to color-blindness, policymakers in the Jim Crow South were not always circumspect about their segregationist purposes. Representative Risley C. Triche of Assumption Parish, Louisiana, for instance argued in the Louisianan House of Representatives in December 1960 that the grant-in-aid system was the most effective weapon against the integration of public schools (Peltason 1971, 228-29). Alabama Governor George C. Wallace called for tuition vouchers in order to hold the line against the threat of integration (Rives, Grooms, and Johnson 1964).

The racist motives of the sponsors of these state schemes did not escape some judges’ attention. A federal district court noted in its 1967 Poindexter ruling that Louisianan officials enacted tuition grants to deny black students equal educational opportunities: ‘ ...For a hundred years, the Louisiana legislature has not deviated from its objective of maintaining segregated schools for white children. Ten years after Brown, declared policy became undeclared policy.' Justice Wisdom added: 'Open legislative defiance of desegregation orders shifted to subtle forms of circumvention although some prominent sponsors of grant-in-aid legislation have been less than subtle in their public expression. But the changes in means reflect no change in legislative ends’ (Wisdom 1968, emphasis added).

The federal courts in this case, and in other segregation voucher cases, saw through the color-blind justifications proffered by southern politicians and struck them down as unconstitutional. 
White supremacist policy design and administration

The educational expense grants were directed according to racial criteria to support segregation academies, entangling the state with racist purposes. Several tuition grant programs paid state funds not only to parents but also to the schools directly. New segregation academies were 'private in name only' (Crespino 2007, 240). Their boosters' notionally-color-blind 'freedom of choice' rhetoric notwithstanding, these earliest voucher programs were designed specifically to sustain the racial hierarchies of the Jim Crow era by embedding racial categories in the design and administration of policy.

Subsequent iterations of tuition grant laws excised explicit mentions of race but the racial purposes of the statutes were clear. Under threat of court action, states attempted to camouflage the connection between government and segregated academies by funding parents and not schools directly. A key rationale was first articulated in Borden v Louisiana (1928). ${ }^{\text {xii }}$ The Court allowed parents a 'free choice' as to where they use their state-funded tuition grant. This trope made the program 'constitutional' by benefiting the child rather than the school directly, (even if the school ultimately banked the money and thereby benefited 'incidentally', the benefit to the student was the statute’s primary purpose). ${ }^{\text {iv }}$ In another effort to shield their program from legal challenge, lawmakers in Louisiana transferred administrative authority from the state Board of Education to a new arms-length agency, the Louisiana Financial Assistance Commission (Carl 2011, 47).

But these efforts to suppress the connection between state and school did not deceive federal courts as cases such as Griffin v County School Board of Prince Edward County reveal (Black 1964). ${ }^{\mathrm{xv}}$ In Griffin, the 'personal, parental, and race-conscious choice to discriminate was rendered de jure by virtue of state funding, which was used to support the voucher program.' In effect 'the Supreme Court thus determined that this "exercising of school choice” with a voucher was a violation of Brown's desegregation mandate' (Gooden, Jabbar, and Mario S. Torres 2016). 
In Hall v Helena Parish (1961) the court said that tuition grant programs were a 'transparent artifice’ designed to circumvent blacks' 'constitutional right to attend desegregated public schools' (Wisdom 1961). ${ }^{x v i}$ In Poindexter (1967), the court stated explicitly: 'The United States Constitution does not permit the State to perform acts indirectly through private persons which it is forbidden to do directly’ (Wisdom 1968).

The temporality of early tuition grant vouchers reveals four different legal and political strategies on the part of southern states to stop desegregation using both direct and indirect methods (Table 3). Vouchers were an element in each strategy.

First, states such as Virginia and Louisiana pursued immediate 'massive resistance' policies in response to Brown, a belligerent, all-in, up-front approach that incorporated school closings, outlawing public school desegregation, tuition grant payments and open defiance, and that ran the greatest risk of legal challenge. Vouchers were one part of the miasma of violent incidents and legal challenges by white segregationists. Secondly, other states including North Carolina deployed a measured approach to slow the pace of desegregation, placate segregationists and reduce the likelihood of court override by authorizing (but not implementing) tuition grants.

Thirdly, border-south states - Maryland, West Virginia, Kentucky and Tennessee - did not pursue tuition grants because they were resigned to at least token integration, particularly those with a small African-American population. Fourthly, states such as Mississippi and South Carolina did not pursue tuition grants at first because, at least initially, they were unnecessary. Policymakers were committed to absolute school segregation and 'most blacks understandably feared violent or fatal repercussions if they chose to press their case legally’ (Bonastia 2012, 77). This last group of states did eventually adopt tuition grants, but many years later than the 'Massive Resistance' group and only when these states’ bulwarks against desegregation had begun to crumble at last. 


\section{[TABLE 3 ABOUT HERE]}

In sum, vouchers were part of the general white supremacy effort to get white children out of the public school system to avoid inter-racial contact. This imperative was most acute in states such as Virginia that overlapped the southern Black Belt, which had adopted a defiant position to federal desegregation law suits but could not rely upon sheer brute suppression to prevent public school desegregation.

To a free market economist such as Milton Friedman it made perfect economic sense that racist legislatures would enact measures such as vouchers to prop up segregation in schools (and logically in other policies such as housing and labor markets) (Friedman 1955); indeed Friedman encouraged the arguments developed by University of Virginia economist James Buchanan in favor of opposing Brown by using vouchers (MacLean 2017, 69-70). But the practice and the theoretical argument were products of and integral to the political supporters of the segregationist racial order. Their chief opponent was the National Association for the Advancement of Colored People (NAACP), and the NAACP's chief weapon in the fight against segregation tuition grants was the courtroom.

Part 2. Shifting racial regimes: vouchers for liberals and race targeting

\section{The origins of Midwestern voucher programs}

In Mississippi, South Carolina, Alabama, Virginia and Louisiana lawsuits ended the segregation vouchers. Congress and the courts became more decisive in embedding civil rights in the decade between 1964 and 1973. As these laws and rulings took effect the blatant use of publicly-financed tuition-grant vouchers for white students to escape desegregation was finally defeated. By 1970, segregation tuition grants had been struck down as unconstitutional across the South, ${ }^{\text {xvii }}$ though segregated institutions, including private segregated academies, remained (Carr 2012). 
More broadly, segregation was legally displaced by the civil rights legislation in the 1960s enacted in response to the demands of the reform movement (Francis 2014; Young and Burstein 1995). Legal and federally upheld segregation encountered decisive legislative defeat in the 1960s as Congress eventually passed laws against it in the mid-1960s. Combined with busing programs and new federal funding made available as a condition of desegregating schools, southern states made dramatic strides to integrate schools between 1968 and 1973 (D. King 2017; Clotfelter 2004).

Court orders were also crucial in ending vouchers as tools of segregated schools. In the north, the voucher cause experienced further set-backs during the 1970s. Segregation was mostly not de jure in the north but de facto present and resistance to school integration was fierce, and often violent, (Douglas 2005).

A federal effort to institute a voucher program in New Hampshire foundered on local-level resistance in 1976 (Carl 2011). A public school voucher demonstration project lasted just five years in the Alum Rock district, California. Voter referenda quashed voucher plans by large majorities. Scattered tuition reimbursement programs in Illinois, Nebraska, New York, Ohio and Pennsylvania were struck down as unconstitutional between 1972 and 1974 on the grounds that they violated the separation of church and state. Unlike segregation tuition grants, these tuition reimbursement programs had incorporated the Catholic schools, which constituted a large section of all private schools then in existence.

Despite support for the idea of vouchers amongst members of the Office of Economic Opportunity during the Great Society era, the Nixon and Reagan administrations, and even liberal academics such as Diane Ravitch and sociologist Christopher Jencks, no major voucher tuition programs were instituted during the 1970s and 1980s (Carl 2011; D. Ravitch 2001). This was an era in which the race-conscious policy alliance's commitment to activist federal policy to advance 
racial equality enjoyed national political support, even if voter resentment toward affirmative action and related measures was brewing (Frymer and Skrentny 1998).

\section{Voucher Designs as Race Targeting}

The reinvented place of vouchers in America's racial hierarchies seemed to arrive in the early 1990s when two major voucher programs passed. Each targeted large urban school systems. The trajectory of America's racial hierarchies subsequently gave a new role to vouchers as part of a color-blind approach to policy. But first some advocates for racial equality were drawn to the potential efficacy of vouchers as a race-targeted instrument. These two phases of race-conscious controversies correspond to the expansion and subsequent retrenchment of minority political rights within the larger trajectory of racial politics in the United States (Jones 2017).

Responding to a perceived crisis of city schools, high drop-out rates, low test scores and a growing urban African-American population still enduring segregation and discrimination, the Wisconsin and Ohio legislatures passed the Milwaukee Parental Choice Program (1990) and the Cleveland Scholarship Program (1995) respectively. Amidst mounting disillusionment and an expanding racial achievement gap, Republican politicians saw a wedge issue on which they could ally with non-white Democrats.

The racial dynamics of predominantly African-American cities within overwhelmingly white states, combined with anger at stalling desegregation, weak public school performance and growing black political power at municipal level generated sufficient support for change (Carl 2011). Polls in the 1990s generally found African-American support for vouchers exceeds that of other racial groups (although responses vary with question-wording). ${ }^{\text {viii }}$

In 1990 Milwaukee and Cleveland were 30\% and 47\% African-American respectively compared to statewide populations that were $92 \%$ and $88 \%$ white (Table 4). 


\section{[TABLE 4 ABOUT HERE]}

Population data in Table 4 underestimates the percentage of African-American enrolment in Milwaukee and Cleveland's public schools because many white students had left the system for parochial schools over the preceding four decades.

The Milwaukee program initially excluded religious schools but in 1995 the legislation was amended to include them. The program started to grow. From an initial enrollment of 258 students in the 1990-91 school year, the Milwaukee program swelled to 27,606 by 2016-17. In Ohio, the Cleveland program temporarily outstripped the Milwaukee program in enrollments but grew more modestly to 8,594 by 2017.

As vouchers moved into a new phase during the 1990s, the separation between the state and the private schools became sharper than it had been even during the era of Jim Crow. Since the Wisconsin and Ohio vouchers allowed religious schools to participate (unlike the segregation vouchers) it was essential to disguise the connection between state and school by the intervention of private parental choice. Both Wisconsin and Ohio have state constitutional provisions known as 'No-Aid Provisions' that prohibit public funding of denominational institutions (Hackett 2014). To avoid running afoul of these constitutional provisions policymakers designed programs that funded parents rather than schools directly.

In the Supreme Court’s 2002 Zelman v Simmons-Harris case this indirect program design acquired legal significance. ${ }^{\text {xix }}$ The majority justices held that: ‘Our decisions have drawn a consistent distinction between government programs that provide aid directly to religious schools... and programs of true private choice, in which government aid reaches religious schools only as a result of the genuine and independent choices of private individuals' (Rehnquist 2002). Although 96\% of recipients used the Cleveland voucher at religious schools, the Court found 'no evidence that the State deliberately skewed incentives toward religious schools' in the way that 
the Jim Crow segregationists had skewed the administration of tuition grants toward segregated schools. In the most extreme case - Prince Edward County - there had simply been no nonsegregated in-county options for tuition grant recipients.

Immediately challenged in court by plaintiffs acting for public school administrators, teacher unions and students, both voucher programs survived Supreme Court review and continued to expand. Figure 3 displays the expansion of voucher enrollments in these two programs as a proportion of the school-age population in each city (Source: US Census Bureau 2010). A quarter of Milwaukee’s school-age population utilized a voucher in 2017.

\section{[FIGURE 3 ABOUT HERE]}

\section{Patterns of support for race targeted vouchers}

Wisconsin's program is an important punctuation in the movement from conservative Democrat to overwhelmingly Republican patterns of voucher support. It rested on a 'strange bedfellow' alliance launched in the late 1980s by Wisconsin state representative Polly Williams. Williams, an African-American Democrat, sponsored the Milwaukee Parental Choice Program legislation allied with conservatives and the state’s Republican Governor, Tommy Thompson, to pass Wisconsin's first voucher program in an effort to improve an urban school system wracked with weak results and growing poverty rates (Hess 2004).

A native of Mississippi whose family had moved to Wisconsin prior to school integration, Williams's advocacy of vouchers was unusual. Her colleague, former schools superintendent and founder of the pro-vouchers group Black Alliance for Educational Options (BAEO) Howard Fuller recalled in a 2014 interview: 'In '88 being a black Democrat saying 'I support vouchers,' that was an unbelievably brave stand' (Prothero 2014). 
Williams proved to be an outlier from most supporters of activist policy for racial equality who campaigned for more spending on public schools in general, rather than selective voucher schemes. Although the use of vouchers as a mechanism for maintaining racial segregation did not appear explicitly in voucher discussions of the 1990s, the presence of race-conscious alliance members within the pro-voucher camp may have helped counter the impression that school choice was ‘a white, conservative movement that takes advantage of unwitting minority families’ (Reid 2001b).

Representative Williams's work on behalf of the voucher cause was an instance in voucher history when the alignment of vouchers with the color-blind racial policy alliance broke down. While Republican conservatives never wavered in their support for vouchers - Governor Thompson had included a voucher proposal in his 1988 budget and Governor George Voinovich pushed Catholic Dioceses to join his voucher effort in Ohio (Voinovich 1991; Pilarczyk 1991, 1993) - Representative Williams’s stance broke the race-conscious alliance’s opposition to vouchers and helped give birth to a new constellation of race-conscious groups seeking to boost vouchers for race-conscious ends. Launched in 2000, BAEO was the lynchpin of that raceconscious pro-voucher alliance. They found some judicial support.

Judicial patterns of support for vouchers

Patterns of political support shifted during the era of race-conscious controversies, and these shifts were mirrored in changing patterns of support by judges in voucher cases. Throughout the 1960s and 1970s courts often found voucher programs unconstitutional. But from the mid-1980s, and particularly since Zelman v Simmons-Harris in 2002 courts became more likely to uphold vouchers’ constitutionality, a vital legal prop for programs enduring fierce criticism from many race-conscious alliance members including the NAACP. This legal imprint complements the post- 
1970s Supreme Court majority’s dilution of affirmative action, set aside hiring and even voting rights (D. King and Smith 2016).

In order to examine patterns of support for vouchers amongst judges, we collect and analyze information on all judicial opinions in voucher cases, 1955-2017, unearthing several empirical trends. First, Republican justices (and those appointed by Republican executives) have been consistently more sympathetic to vouchers than Democratic justices, mirroring Republican policymakers’ support for voucher bills. Second, Southern justices were more sympathetic to vouchers than western ones. And third justices have become more likely to uphold vouchers as constitutional over time, findings consistent with Hackett's analysis of the broader universe of religious school aid programs (Hackett 2017b). This last trend extends the judicial patterns of the 1960s.

These findings show how during the transition of racial regime from segregation to the civil rights era, judicial decisions played a key role in facilitating the revival of vouchers despite their earlier rulings. This is part of America’s racial trajectory. It illustrates how racial hierarchies are reconfigured along new divisions between active racial equality reformers and those opposing the use of federal policies for equality, a dichotomy along the lines of King and Smith’s raceconscious versus the color blind policy alliances.

Our database contains 229 individual justice votes on voucher cases, including opinion writers, concurring decisions and dissents. This is the universe of cases. We subject our database to logistic regression with standard errors clustered by court to examine the effect of justice and state characteristics upon judges' likelihood of voting in favor of vouchers (Table 5). The dependent variable is coded 1 if the justice voted to uphold a voucher as constitutional, 0 otherwise. $^{\mathrm{xx}}$

[TABLE 5 ABOUT HERE] 
Our regression shows that the patterns of support in courtrooms mirror patterns of support amongst policymakers, with Republicans most likely to vote in favor of vouchers even when controlling for sex, race and other variables. Compared to Southern judges we find that Westerners are less likely to uphold voucher programs as constitutional. Voucher bills have been held constitutional at a much faster rate in recent years, as the statistically significant result for the date of program challenge indicates. Republican-appointed judges are more likely to uphold voucher programs than Democratic-appointed judges.

The key difference between legislative and judicial realms before the breakdown of Jim Crow is that Democratic justices struck down policies passed by Democratic majorities. This split reflects the division between the Democratic Party's northern and southern wings during that racial epoch. Most baldly, Democratic federal court judges confronted measures passed by racially-conservative Democratic majorities in southern legislatures.

The clash between segregationist and anti-segregationist racial policy alliances is amply illustrated in decisions such as Harrison v Day (1959), Hall v St Helena Parish School Board (1961), and Lee v Macon County Board of Education (1964), which found Virginian, Louisianan and Alabaman tuition grant programs, respectively, unconstitutional (Eggleston 1959; Wisdom 1961; Rives, Grooms, and Johnson 1964).

Since the Jim Crow era, as partisan distinctions between race-conscious and color-blind alliances have inflamed, the Republican Party has continued to move toward racial conservatism and the Democratic Party broadened its racial liberalism (Feinstein and Schickler 2008; Schickler 2016). Republican justices remain more sympathetic to voucher programs than Democratic justices but they now mostly confront Republican rather than Democratic legislation. During the era of race-conscious controversies from the 1980s onwards, judges became more supportive of voucher programs. 
The switch from 'freedom of choice' to racial equality frames (and back again)

Although the Cleveland voucher program was held constitutional in the US Supreme Court case, Zelman v Simmons-Harris in 2002, voucher bills grew at an indifferent rate during the following decade (Carl 2011; Forman 2007). Enrollments in the Milwaukee and Cleveland programs continued to rise (Figure 3) but surprisingly few voucher bills were introduced in other state legislatures or passed by referenda. During George W. Bush's time in office just eleven voucher programs were created at state level and a federally-funded voucher program inaugurated for Washington D.C. Several were struck down in court on First Amendment grounds, including programs in Colorado and Florida (see Figure 1). This period of sluggish growth extended to the 2000s.

James Forman concluded in 2007 that school vouchers failed to expand after Zelman because the sorts of arguments mustered in favor of vouchers did not resonate among the constituencies whose support they needed. In Forman's formulation, early advocates framed their pro-voucher arguments as a 'values claim'. Vouchers protected the right of parents to send their child to a school that reinforced their values. This framing rallied Christian conservatives to the voucher cause between the 1970s and the 1990s. It was also a core element of southern segregationists' 'freedom of association' framing during the 1950s and 1960s, a color-blind facade to conceal their racist purposes.

Beginning in the 1990s, Forman argues that supporters of vouchers switched from the 'values claim' to a 'racial justice claim' that emphasized the right of low-income and minority parents to send their children to academically rigorous private schools. The Wisconsin program fits this characterization. Representative Williams criticized public school desegregation plans for making black children 'get up at 5 a.m., standing out in the dark and cold, so they can be bused to some faraway place where no one teaches them anything. [The white establishment] controls 
everything. White bus companies, white businesses, white suburbs...they get millions upon millions on account of Chapter 220 [the then 25-year-old desegregation plan]' (Ruenzel 1995).

Forman concludes that, 'the racial-justice claim asserted that vouchers provided educational emancipation for poor students, mostly black, trapped in dysfunctional urban districts' (Forman 2007, 551). A switch in the 'public face, intellectual rationale, and legal defense' of the voucher movement toward explicitly race-conscious arguments made the legal defense of the Cleveland voucher program easier, although it failed to resonate with white constituencies.

The new focus on helping minorities, rather than First Amendment issues, appealed to a majority of the Supreme Court. In his concurring opinion in Zelman, Justice Clarence Thomas wrote: 'the failure to provide education to poor urban children perpetuates a vicious cycle of poverty, dependence, criminality, and alienation that continues for the remainder of their lives.' He declaimed: 'If society cannot end racial discrimination, at least it can arm minorities with the education to defend themselves from some of discrimination's effects' (Zelman v Simmons-Harris 2002).

In the 1962 reprint of his essay on The Role of Government in Education Milton Friedman removed the footnote which had positively identified the southern programs designed to circumvent de-segregation after the Brown ruling as leading examples of vouchers (Friedman 1955; Chubb and Moe 1990; Carl 2011). Friedman could obviously scent the political times and the racial equality tilt in national politics. His caution was shared widely by voucher advocates. When vouchers re-emerged as a major force in the 1990s, proponents now advanced a different set of rationales based on race-consciousness and targeting rather than the defense of racial inequality.

Members of the pro-voucher coalition advanced the framing of school vouchers as 'the civil rights issue of our time' (Snow 2016). It was a deliberate strategy on the part of voucher supporters and their legal team in the Zelman decision, headed by Clint Bolick, co-founder of the 
pro-voucher organization Institute for Justice (Minow 2010). Their aim was to expand the base of support for vouchers and to help shore up its legal defense by claiming the mantle of the civil rights struggle in education (Persson 2015). Dr Martin Luther King Jr’s niece Alveda King endorsed school choice as a civil right in a Wall Street Journal op-ed (A. C. King 1997). Pennsylvanian Governor Tom Corbett echoed Louisianan Governor Bobby Jindal, also Republican, in calling vouchers 'the civil rights issue of the twenty-first century' (Infield 2010).

One signal of the extent to which vouchers had been re-imagined since their origins as instruments of segregation came in 2011, when the Pennsylvanian Democrat State Senator (and African-American) Anthony H. Williams compared opponents of vouchers to segregationists: 'Standing in the way of school choice for needy kids in failing urban schools is like Gov. George Wallace standing in the doorway of a classroom to continue the segregation of the '60s' (Worden and Hardy 2011). Historian Martha Minow concludes that, ‘Clint Bolick’s strategy...paid off. Identifying poor black and Hispanic children as beneficiaries and aligning school choice with civil rights rather than against it seemed to work...Public attitudes about school choice depended in no small part on the framing of the issue' (Minow 2010, 122).

Yet despite these efforts to claim the mantle of the civil rights movement, voucher growth was tepid into the first decade of the twenty-first century. Forman argues that such race-conscious claims repelled white conservatives. The true voucher renaissance was still to come, nourished by the ascendance of the increasingly confident color-blind alliance.

Part 3. Vouchers in the civil rights era: the color-blind resurgence Modern voucher growth and racial spillover in the Obama era The real push for vouchers by state legislatures came mid-way through Barack Obama’s first term as newly-elected Republican legislatures started to exploit the Zelman clearance. This new thrust was a direct response to the heightened racial polarization of Obama’s presidency and not 
confined to education policy. It was abetted by a shift in governance toward Republican control of state government after 2010 in legislatures across the country. Newly unified Republican governments in Indiana, Wisconsin, Alabama, Pennsylvania, North Carolina and New Hampshire all passed voucher bills in the two years following the 2010 elections.

Just as his health care reform divided voters by race, so the Obama presidency galvanized opponents of racial equality to use vouchers as a means to keep education segregated (D. King and Smith 2014; Frankenberg and Siegel-Hawley 2010; Hackett 2017a). The striking rise of vouchers is not causally explained by America’s increasing racial polarization but the correlation is hardly racially neutral. Tesler explains a similar contagion as racial spillover (Tesler 2012). In the era of an African-American president, public policies notably health care and gun control regulation become racialized in that voters view these issues through the prism of their racial policy preferences. Racial spillover spread into vouchers (Samson 2012; Tesler 2016).

The use of race-conscious frames may have aided the legal defense of vouchers, but the literature on racialization demonstrates that the general public is negatively disposed to raceconscious measures aimed at aiding blacks (Tesler 2016; Valentino, Hutchings, and White 2002; Gilens 1996). Using 'racial justice’ claims weakened the voucher cause by focusing on school underperformance. This emphasis opened the door for greater regulation of private schooling and alienated white conservative Christians, thus dooming the voucher cause as former supporters deserted it (Forman 2007). But other support was at hand. When vouchers were rediscovered again by Republican state legislatures after 2010, color-blind frames were ascendant nationally even though these advocates felt the need to gesture toward potential race targeted gains from vouchers.

Two thousand and eleven has been declared 'the year of school choice.' It was merely a starting-gun. Seven programs were created in 2011 alone, six in 2012, nine in 2013, and twelve more by the end of 2016. Design varied. Some utilized tax credits and intermediary organizations 
for the distribution of grants. Other programs took an individualized savings account model, but all subsidized parents' choice of private school tuition.

Southern legislatures embraced vouchers enthusiastically. Mississippi and Virginia passed their first modern voucher programs in 2012; Alabama and both Carolinas in 2013. By 2016 all seven of the original segregation tuition grant states had passed new voucher bills. Indeed, Alabama, Georgia, Louisiana, Mississippi and South Carolina each had more than one such program. These were impeccably color-blind initiatives.

In this modern period, voucher programs stretched from Montana to Maryland and from New Hampshire to Nevada. Western states were generally less receptive to vouchers although states such as Arizona and Nevada embraced them. Enrollments grew to more than half a million children nationwide across thirty states. In 2015, by our estimate, 665,760 students used some form of voucher. Figure 4 displays the growth of enrollments in voucher programs as a proportion of the school age population in selected states (Sources: Edchoice.org; US Census 1990; 2000; 2010).

\section{[FIGURE 4 ABOUT HERE]}

As Figure 4 shows, vouchers serve around 6-7\% of the school-age population in school choice hotspots Indiana and Wisconsin, three times as many, proportionately, as were served by tuition grants in the Deep South after Brown.

The take-up of modern voucher programs varies depending upon the characteristics of the program and the state. By 2018 we calculate that there were eighteen programs targeted at disabled students (most in the South), sixteen programs targeted at low-income groups (most in the Midwest), two programs for students in failing schools, twelve programs with multiple eligibility requirements and twelve universal programs with no eligibility limits (EdChoice 
2018). ${ }^{\mathrm{xxi}}$ Compensatory programs (those with income limits for participation) and those targeted at cities tend to attract a greater proportion of black participants. 'Universal' programs such as those enacted by Indiana place no income or geographical limits on voucher participation and so tend to be dominated by whites, mirroring the disproportionate take-up of public tuition grant funds during the era of segregation (Brunner, Imazeki, and Ross 2006; Potter 2017; Carl 2011, 2).

Some states conspicuously failed to pass such programs, however. None of the three most populous states (California, Texas and New York) had passed vouchers by 2017. New York and California were bastions of the liberal, increasingly Democratic race-conscious alliance so their absence is unremarkable. In Texas at least six legislative efforts to enact vouchers failed in committee or on the floor, defeated by a strange-bedfellow state-based coalition of Democrats, rural Republicans fearing the loss of public school provision, and homeschoolers and Baptist groups fearful of governmental intrusion into religion, which has (so far) repelled federal provoucher organizations by campaigning for a distinctively Texan approach (Garrett 2017). ${ }^{\text {xxii }}$

\section{Racial alliances and patterns of support for vouchers}

The race-conscious alliance's opposition to vouchers looked precarious during the 1990s. But the mainstream civil rights organizations mobilized and prevailed. The NAACP and its local chapters organized vigorous opposition to vouchers. Aside from BAEO the number of race-conscious proponents of vouchers remained small, with a mere handful of state- and locally-based groups, such as Hispanics for School Choice, a Wisconsin grouping, and Black Clergy of Philadelphia, mobilizing on behalf of school vouchers during the most recent push for vouchers starting in 2011 (Rodriguez 2011; Bunch 2011). BAEO disbanded in 2017.

Well over ninety percent of voucher bills passed since Representative Williams’s efforts in Wisconsin were created by color-blind alliance members and opposed by race-conscious alliance members. Between 1990 and 2017, seven programs passed Democratic-controlled legislatures, 
including in states such as Louisiana and Maryland with large African-American populations, but they were dwarfed by the forty-eight programs that passed under unified Republican control.

To examine patterns of voucher bill support we collate an original dataset of all state legislative votes on the forty-seven voucher bills passed in the twelve years to 2017 .xiii $^{\text {Our }}$ dataset contains the universe of state legislators who voted on those bills in 6,693 votes plus twelve voucher bills that were brought to a vote before July 2017 but failed to become law because they were vetoed or voted down, yielding a total of 7,851 state legislator votes. We subject our data to multilevel logistic regression in order to identify those factors that affect policymaker support for vouchers, modelling state legislators’ votes in terms of their individual and district-level characteristics (partisan affiliation, race and sex; district ideology, private school enrollment, racial district characteristics and government employees) and state level characteristics (educational expenditure, unionization rates and previous legal challenges).

\section{[TABLE 6 ABOUT HERE]}

Our findings in the main effects model (Table 6) underline the extent to which raceconscious and color-blind patterns of support have become polarized. As expected Republicans are much more likely to vote for a voucher bill than Democrats but there is a statistically significant interaction with their state legislative district ideology, displayed in the interactive model in Table 6.

To pinpoint state legislative district ideology we utilize the American Ideology Project (2015) MRP scores on district ideology after the 2010 census redistricting (Tausanovitch and Warshaw 2013). ${ }^{\text {xxiv }}$ The more conservative their district, the more Democratic legislators are likely to vote in favor of vouchers. The effect is substantial and asymmetrical. A Republican state legislator has around an 85\% chance of voting in favor of a voucher bill regardless of his or her 
district's ideology. By contrast a Democratic state legislator with the most conservative district is more than twice as likely (42\%) to vote in favor of a voucher bill than a Democratic legislator with the most liberal district (18\%), as Figure 5 shows.

\section{[FIGURE 5 ABOUT HERE]}

But Figure 5 finds that even a Democrat representing a conservative district still has a much smaller chance of voting in favor of vouchers than a Republican. Color-blind alliance members Republicans and conservatives - overwhelmingly predominate amongst voucher supporters. Greater rates of unionization also have a statistically significant negative effect upon legislators' chances of voting for vouchers. This finding underlines the teacher union presence as part of the Democratic coalition and race-conscious voucher opposition movements (D. King and Smith 2011), and union concern about vouchers’ potential to damage public schools (Dorfman 2016).

We have already noted how racial and ideological polarization has intensified in the last decade and a half (Barber and McCarty 2016; Tesler 2016), a trend reflected in the results. This growing polarization between the racial policy alliances means that voucher support aligns along partisan lines more sharply than during the era of Jim Crow, when Democratic judges struck down Democratic voucher legislation. Formerly enthusiastic liberal supporters of vouchers, such as Diane Ravitch, began to turn against the voucher cause after 2010 (D. Ravitch 2013). They have become some of vouchers' fiercest critics.

The color-blind alliance on school vouchers is complicated by the characteristics of legislators' districts. White legislators (and males) are statistically significantly more likely to vote in favor of vouchers than non-white legislators and females. But our data shows that the proportion of African-Americans in a legislator's district is positively related to a vote in favor of vouchers (Table 6). Despite the opposition of most civil rights organizations and the dominance of 
conservative organizations such as the American Federation for Children, Cato Institute, Institute for Justice and Goldwater Institute within the pro-voucher movement, the main effects model shows that legislators with the highest proportion of African-Americans in their districts are fifteen percentage points more likely to vote in favor of vouchers ( $77 \%$ chance) than legislators with the highest proportion of whites (62\% chance).

This striking datum recalls the patterns of support for tuition grant legislation in the Jim Crow South. Legislators with the whitest districts were, and still are, the least enthusiastic about the voucher cause.

One explanation for white districts' relative reluctance is Forman’s argument that racial justice claims for vouchers fail to resonate with core white voucher constituencies (Forman 2007). Another possibility is that, despite their color-blind presentation, the race-conscious reimagining of vouchers during the first decade of the civil rights era activates feelings of racial threat amongst whites (Bobo 1998; Bobo, Kluegel, and Smith 1997; Tesler 2012).

We cannot distinguish these two explanations here but note the interaction between a legislator’s party and his/her district racial characteristics. Republican legislators representing districts with a larger proportion of African-American voters are less likely to support voucher legislation than Republicans representing whiter districts; Democratic legislators representing districts with a larger proportion of African-American voters are more likely to support vouchers than Democrats in whiter districts (Figure 6).

\section{[FIGURE 6 ABOUT HERE]}

Figure 6 suggests that at least some Democratic legislators perceive demand for vouchers from black constituents - an inference we cannot make firmly on the basis of this data - but the elite politics of vouchers remains resolutely framed by the race-conscious/color-blind distinction. 
Nonwhite legislators and Democrats are significantly less likely to support vouchers than white legislators and Republicans. The racial dimensions of vouchers tend to remain implicit in the contemporary racial order and buried beneath color-blind frames, to which we now turn.

\section{Back to 'freedom of choice' frames}

Modern arguments for school vouchers tend to be color-blind, at least on the surface. Legislators argue in favor of vouchers for poor children, implying that racial minorities are the target population without emphasizing race directly (O’Brien 1996; Gooden, Jabbar, and Mario S. Torres 2016). Gooden and colleagues find: 'Contemporary case law, state statutes, and politicians who are proponents of vouchers have tended to adopt a race-neutral approach to using vouchers to address equity. This does not, however, mean that race is not a part of this debate’ (Gooden, Jabbar, and Mario S. Torres 2016, 523). In the context of America’s modern racial hierarchies and post-2008 intensified racial and ideological polarization, color-blind claims for vouchers may be promoted as impartial but few voters or law makers can fail to grasp their racial implications.

Drawing upon a sample of 526 broadsheet newspaper articles drawn from Factiva for the twelve states that passed voucher programs in 2011 and 2012, the first years of the most recent voucher expansions, we find color-blind rationales overshadow race-conscious ones. A full description of method and coding procedures is available in the endnotes. ${ }^{\mathrm{xxv}}$ Seven of these twelve states had no reporting of explicit racial claims for or against vouchers at all. In the remaining five, claims for vouchers as a remedy for racial inequality were infrequent compared to choice, quality and efficiency arguments.

In all states color-blind framings predominated, focusing on individual parents rather than racial groups and eschewing racial language. The most common arguments cited in favor of vouchers were that they save money, improve educational quality and increase access to educational opportunity for students and choice for parents. The most common arguments against 
vouchers were that they drain money from the public school system, defy the legislature's obligation to provide a good, uniform system of public education and violate the separation of church and state by providing funds to religious schools. Explicitly race-conscious arguments that vouchers would address racial inequality were rare. Vouchers are framed in color-blind ways.

\section{The rise of color-blind policy design}

The rise of the color-blind racial policy alliance is associated not only with color-blind patterns of support and rhetorical frames but also with color-blind policy designs. A race-conscious policy design utilizes explicit racial categories to confront racial inequalities directly through government action (what Justice Sonia Sotomayor calls 'race targeting’ measures), whereas colorblind policy designs favor a market-driven ‘free choice’ approach by individual consumers. President Obama’s Department of Justice fought some modern voucher programs in the South on the grounds that the programs have the potential to undermine existing court-ordered desegregation plans by enabling parents to opt out for private schools (Walsh 2013).

Modern, 'universal' voucher programs - such as the tax credit vouchers in Arizona and Georgia - place no income limits on student eligibility and in some cases, no requirement to have spent time in the public school before taking up a voucher. Race-conscious policy alliance members argue that targeting is required to ensure that children of color benefit and that public money is not distributed to economically advantaged households, who would have sent their children to private school regardless. When Representative Polly Williams and former Milwaukee superintendent Howard Fuller championed vouchers in 2010 they argued that the programs should not be extended to higher income groups but instead should focus only on low-income minorities, a further cooling in race-conscious support for the new vouchers and the surge of color-blindness (Marley 2013; Marley and Stein 2011; Bice 2013). By 2018 BAEO had dissolved. 
The rise of the color-blind policy design tends to obscure the state's role in the provision of a social benefit by directing funds through private third party organizations or through the tax system (Mettler 2009). Voucher policy designs became more 'submerged', utilizing private organizations or the tax system to deliver benefits. By funding parents rather than schools directly and utilizing tax credits and 'educational savings accounts', modern voucher programs individualize social policy decisions and obscure the relationship between state action and the confrontation of racial inequalities that is the hallmark of race-conscious policymaking.

The fight between advocates of compensatory vouchers and those who favor 'universal' vouchers mirrors the clash between race-conscious and color-blind forces. It has been sharpened by the recent finding that color-blind voucher statutes provide insufficient protection against racial discrimination in private school admissions (Eckes, Mead, and Ulm 2016). In May 2017, under questioning from House appropriations committee members, US Secretary of Education Betsy DeVos declined to say if the federal government would step in to prevent voucher-receiving private schools from discriminating against students (Resmovits 2017). DeVos argued that decisions should be left to parents, an approach to voucher politics that is quintessentially colorblind in its elevation of individual choice over direct and purposeful state action.

Reducing the traceability of the connection between government and policy administration is a characteristic of color-blind policymaking. Individuals make choices in private markets that are officially color-blind and the state is merely a neutral umpire. This submerged form of governance is the opposite of race-conscious policymaking which involves direct state action to remedy racial disadvantage.

The Trump administration's FY2018 budget includes federal grant money to pay for school vouchers, delivering money indirectly, but faces opposition from Democrats and rural Republicans. A Department of Education spokesperson stated: 'To be clear, there is no federal voucher program. The [private school voucher] grant program would support states who apply for 
funding to develop school choice programs, and those States' plans must adhere to Federal law' (Ujifusa 2017). This color-blind arms-length form of governance is increasingly characteristic of voucher politics.

\section{$\underline{\text { Conclusion }}$}

Are vouchers truly color-blind or race-conscious? We have argued the answer depends upon the historical context of America’s racial hierarchies under examination. We have employed and refined the racial orders theoretical framework to account for the trajectory of vouchers since their origin in the 1950s.

Although the voucher schemes differ across the three epochs there are significant resonances because of the way in which public policy is shaped by America's racial orders. One such parallel between Jim Crow era tuition grants and modern vouchers is that, when allowed to do so, parents who already send their children to private schools will tend to consume vouchers to a greater extent than parents whose children are in public schools. For example, $86 \%$ of Georgian tuition grant recipients in 1962 had already been enrolled in private schools before the fight over desegregation (Kruse 2005, 171). Thus grants tended to benefit those, principally whites, who already had the means to fund private education.

We argue that to understand the voucher renaissance observable since 2008, these measures must be located historically in America's racial hierarchies. This approach reveals how vouchers were directed toward white supremacist ends, briefly harnessed by the race-conscious alliance, and are now part of the conservative ideology of color-blindness that has surged since the Reagan era, bursting into the presidential election in 2016. This historical legacy illustrates the non-linear trajectory of vouchers in America’s shifting racial orders.

This trajectory is more than the 'layering' of new policies onto existing schemes, one form of American political development scholars identify. It qualifies the process of 'displacement' 
described by Skowronek and Orren of which the 'overthrow of Jim Crow was a major' instance (Skowronek and Orren 2016, 29). Yes, Jim Crow was displaced in national institutions, laws, norms and routines, but unremarkably the resilience of racial orders ensures that the contemporary voucher programs echoes the racial hierarchies prompting their origin.

We identify multiple concurrent and consecutive transformations in voucher politics over time in three arenas of racial policy alliance conflict: multiplication of color-blind policy designs, growing legal and political support from a conservative alliance, and a smorgasbord of voucher rationales rooted in color-blind framing. Vouchers have never been racially neutral, but have served key roles with respect to the evolving racial politics of the post-Brown era. By examining the roles vouchers have played in the making and unmaking of racial hierarchies over time, we deflate the myth of their racial neutrality and show their contribution to the rise of color-blind ideology in national US politics.

\footnotetext{
${ }^{i}$ We use the term 'voucher' to refer to all types of program that offer a sum of public money to parents to spend on their child's education at a private school of their choice, whether they are 'tax credit scholarship' vouchers, 'tuition grants', or 'educational savings accounts'.

ii Other commentators are beginning to acknowledge the racist origins of school vouchers (Ford, Johnson, and Partelow 2017)

iii Some black children also received tuition grant vouchers, which could be used only in segregated black schools.

iv Of course the division between these periods of racial orders is a heuristic device and there is no absolute movement across the dates.

${ }^{\vee}$ Brown $v$ Board of Education of Topeka, 347 U.S. 483 (1954)

vi Segregation tuition grants were not the first forms of school choice but they were the first programs of any scale that offered grants to parents to exercise their 'freedom of choice' of a private school. Scattered programs enacted after the first and second world wars had paid for tuition for the children of returning servicemen. Town tuitioning programs in rural areas of Maine and Vermont, established in the late nineteenth century and still in operation, pay for public or nonreligious private school for students from towns without a public school, but fewer than $5 \%$ of students in each state are eligible for these programs and tuition is paid directly to the receiving school rather than to parents.

vii Grants were not distributed until 1961

viii Grants were not distributed until 1962

ix After being struck down as unconstitutional, the program was repackaged by state legislators in 1959

${ }^{x}$ Poindexter v Louisiana Financial Assistance Commission, 275 F.Supp. 833 (E.D. La. 1968)

${ }^{x i}$ Coffey v State Educational Finance Commission, 296 F.Supp. 1389 (S.D. Miss. 1969)

xii There are slight differences between different sources in reports of the exact number of vouchers issued for the years 1959, 1961 and 1964, but in each case the number is small. We have taken the source that cites an issuance figure alongside a more exact financial outlay (for example, '\$1,034,392' as opposed to 'over \$1m') as the more reliable. There
} 
are no precise figures for 1968 and 1969. Contemporaneous news sources tell us only that 'nearly 14,000' vouchers were issued in Virginia in 1967 and 'more than 13,000' in 1968.

xiii Borden v Louisiana State Board of Education, 168 La. 1005 (1928)

xiv There are a handful of instances of parents utilizing state-funded tuition grants to send their children to integrated schools.

${ }^{x v}$ Griffin v County School Board of Prince Edward County, 377 U.S. 218 (1964)

xvi Hall v St Helena Parish School Board, 197 F. Supp. 649 (E.D. La. 1961)

xvii The relevant cases are Harrison v Day, 106 S.E.2d 636 (Va. 1959); Hall v St Helena Parish School Board, 197 F. Supp. 649 (E.D. La. 1961); Pettaway v County School Board of Surry County, Va. (230 F.Supp. 480 (E.D. Va. 1964); Griffin v County School Board of Prince Edward County, 377 U.S. 218 (1964); Lee v Macon County Board of Education, 231 F.Supp. 743 (M.D. Ala. 1964); Poindexter v Louisiana Financial Assistance Commission, 275 F.Supp. 833 (E.D. La. 1968); South Carolina Board of Education v Brown, 393 U.S. 222 (1968); Coffey v State Educational Finance Commission, 296 F.Supp. 1389 (S.D. Miss. 1969)

xviii Polls during this period generally showed that African-Americans were more supportive of vouchers than other racial groups: 76\% support in a 1992 National Catholic Education Association poll; 62\% support in a 1997 Phi Delta Kappa/Gallup poll (compared to 47\% amongst white respondents); 57.3\% support in a 1997 Joint Center for Political and Economic Studies poll (compared to an evenly divided white response) (Lawton 1992; Coles 1997; Hill 1998). However, exit polls in California and Michigan voucher ballot initiatives showed no difference or lower support for vouchers amongst blacks than amongst whites, and other nationwide polls displayed greater skepticism of vouchers by AfricanAmericans: for example, 41\% of African-Americans “strongly oppose” vouchers in a 2001 Zogby International poll compared to 32\% in the whole sample (Reid 2001a; Leal 2004). Voucher opinions are highly sensitive to question wording.

xix Zelman v Simmons-Harris, 536 U.S. 639 (2002)

xx There are no statistically significant effects for a justice's race or sex likely due to the small proportion of justices that are either non-white ( $5 \%$ of cases) or female (14\% of cases)

xxi We exclude the "town tuitioning” programs in New Hampshire, Maine and Vermont from this count, because these nineteenth-century programs apply only to districts that lack an existing public school.

xxii Opposition to vouchers in Texas comes from an alliance of Democrats and Republican lawmakers with rural and suburban constituencies. For example in the 2017 votes on SB1, a failed voucher bill, 62\% of Republican lawmakers from less urbanized districts (those with an urbanized population of less than $80 \%$ according to the U.S. Census Bureau) voted against vouchers while $67 \%$ of Republican lawmakers from more urbanized districts (greater than $80 \%$ urbanization) voted in favor. In short, Texan Republicans from less urban districts helped scupper voucher bills alongside Democrats. This opposition may be related to practical questions about the viability of school choice in less-populated areas and concern about loss of public school jobs as much as fears of government regulation of private religious schools or perceptions of racial threat to white suburban school districts.

xxiii We exclude the Colorado Douglas County school board voucher pilot, launched in 2011 as it is the only program created at the local school district level. All other programs were passed by state legislatures.

${ }^{\text {xxiv }}$ MRP scores estimate the mean ideology of each state legislative district. They are based on the 2008-2014 Cooperative Congressional Election Study (CCES). For more information on the methodology used to estimate district ideology scores, see Tausonovitch and Warshaw (2013) and http://americanideologyproject.com/

${ }^{x x v}$ Newspaper Coding Procedures: Analyzing Factiva for newspapers with thirteen programs in the twelve states in which voucher scholarships were passed during either 2011 or 2012, we create an original database of 526 broadsheet newspaper articles. Articles are drawn from 65 state newspapers and 9 additional online news sources in these 13 states. Identification and coding involves all named actors and groups that took a stance on vouchers expressed by: lobbying, attacking, defending, or ruling for or against the scholarships in court, sponsoring legislation or voting for or against the scholarships in the legislature, vetoing or signing a scholarship bill, articulating an editorial opinion, releasing a press statement, or otherwise making a public declaration in favor of or in opposition to scholarships. A total of 835 separate actors are individually identified and logged in our database. Newspapers in more than half of the case study states had no reporting of explicit racial claims for or against vouchers at all.

On at least three separate occasions during this period, explicit race-conscious arguments made by elites for and against vouchers attracted such criticism that they needed to be re-articulated in color-blind terms: (1) the allegations made by both proponents and opponents of the expansion of the Milwaukee Parental Choice Program that the other side is racist (Marley 2013; Marley and Stein 2011); (2) re-articulation of voucher support in color-blind terms in North Carolina (Bonner 2011; Ashley 2014; J. Ravitch 2014; Childress 2013).; (3) remarks about African-American families by the 
Racine Unified School District superintendent about the Milwaukee voucher program that surfaced during the 2013 debates about vouchers (Tenbrink 2013).

Addressing bias: We address the dangers of bias rising from newspaper selection and coding procedures through comprehensive searches and transparent coding methods (Franzosi 1987). We examine all state newspapers in the Factiva database for each of the twelve case study states, searching in each case for the terms "education voucher/tax credit scholarship, separately and in conjunction with the name of the relevant bill and the bill number. Our analysis includes all state newspaper articles mentioning the relevant piece of legislation, however briefly: its formulation, passage, implementation, effects and, in some cases, litigation. Certain newspapers may have chosen to cover education vouchers more frequently than other sources, and these editorial choices may be related systematically to ideological stance, support for vouchers or other relevant variables. Indeed, we expect this to be the case. Given that we are concerned with how the media typically frames voucher arguments, any systematic biases of these kinds do not invalidate inference. 


\section{References}

Anderson, Carol. 2016. White Rage. New York: Bloomsbury.

Ashley, Jamica. 2014. 'CHCCS Joins Suit against State over Vouchers'. The Herald Sun, 11 January 2014.

Associated Press. 1960. 'Tuition Grant Law Praised by Almond'. The Washington Post, Times Herald, 3 December 1960.

. 1961a. 'Virginia Tuition Grants Increase'. The Washington Post, Times Herald, 17 May 1961.

. 1961b. ‘Tuition Grant Cost Rises in Virginia to \$1.7 Million'. The Washington Post, Times Herald, 3 August 1961.

. 1963. 'Tuition Grant Law Rapped by School Head for Roanoke'. The Washington Post, Times Herald, 13 November 1963.

. 1965a. 'White School Faces Challenge in Selma'. New York Times, 28 July 1965.

. 1965b. 'Tuition Grants Voted by Alabama Senate'. The Washington Post, Times Herald, 8

August 1965.

1969. 'NAACP Won't Appeal Tuition-Grant Ruling'. The Washington Post, Times Herald, 22 February 1969.

Baker, Robert E. 1962. '1600 in Northern Virginia Area Apply for State Tuition Grants'. The Washington Post, Times Herald, 2 December 1962.

Barber, Michael, and Nolan McCarty. 2016. 'Causes and Consequences of Polarization'. In Political Negotiation: A Handbook, edited by Jane Mansbridge and Cathie Jo Martin. Washington DC: Brookings Institution Press.

Bice, Daniel. 2013. 'School Voucher Battle Erupts with Charges of Racism and Religious Bigotry'. The Wisconsin Journal Sentinel, 29 May 2013.

Black, Justice. 1964. Griffin v. County School Board of Prince Edward County (Va.), 377 U.S. 218. Supreme Court of the United States.

Bobo, Lawrence. 1998. 'Race, Interests, and Beliefs About Affirmative Action: Unanswered Questions and New Directions’. American Behavioral Scientist 41 (7): 985-1003. https://doi.org/10.1177/0002764298041007009.

—. 2017. 'Racism in Trump's America: Reflections on Culture, Sociology, and the 2016 US Presidential Election'. The British Journal of Sociology 68 (S1): S85-104.

Bobo, Lawrence, James R. Kluegel, and Ryan A. Smith. 1997. 'Laissez-Faire Racism: The Crystallization of a Kinder, Gentler Antiblack Ideology’. In Racial Attitudes in the 1990s: Continuity and Change, edited by Steven A. Tuck and Jack K. Martin. Greenwood, CT: Praeger Publishers.

Bolton, Charles C. 2005. The Hardest Deal of All: The Battle Over School Integration in Mississippi, 1870-1980. The University Press of Mississippi.

Bonastia, Christopher. 2012. Southern Stalemate: Five Years without Public Education in Prince Edward County, Virginia. Chicago and London: University of Chicago Press.

Bonner, Lynn. 2011. 'Two Views of GOP Agenda'. News Observer, 29 April 2011.

Brandwein, Pamela. 2011. Rethinking the Judicial Settlement of Reconstruction. New York: Cambridge University Press.

Brunner, Eric, Jennifer Imazeki, and Stephen L. Ross. 2006. 'Universal Vouchers and White Flight'. University of Connecticut: Departmet of Economics Working Paper Series.

http://digitalcommons.uconn.edu/cgi/viewcontent.cgi?article=1038\&context=econ_wpapers.

Bunch, Will. 2011. 'Pennsylvania: Voucher Ground Zero'. The Philadelphia Daily News, 23 May 2011.

Butzner, John D. 1964. Pettaway v County School Board of Surry County, 230 E.D. Va. 480. U.S. District Court for the Eastern District of Virginia. 
Carl, Jim. 2011. Freedom of Choice: Vouchers in American Education: Vouchers in American Education. ABC-CLIO.

Carper, Elsie. 1960a. 'Virginia Tuition Grants Go Astray'. The Washington Post, Times Herald, 2 January 1960.

. 1960b. 'Tuition Grants Seen Hurting Va. Schools'. The Washington Post, Times Herald, 20 November 1960.

Carr, Sarah. 2012. 'In Southern Towns, "Segregation Academies” Are Still Going Strong - The Atlantic'. The Atlantic, 13 December 2012.

https://www.theatlantic.com/national/archive/2012/12/in-southern-towns-segregationacademies-are-still-going-strong/266207/.

Catsam, Derek Charles. 2009. Freedom's Main Line: The Journey of Reconciliation and the Freedom Rides. Civil Rights and the Struggle for Black Equality in the Twentieth Century. Kentucky: The University Press of Kentucky.

Chen, Anthony S. 2009. The Fifth Freedom: Jobs, Politics, and Civil Rights in the United States, 1941-1972. Princeton: Princeton University Press.

Childress, Gregory. 2013. 'Local Groups to Rally against GOP Policies’. The Herald Sun, 26 May 2013.

Chin, Gabriel J., Roger Hartley, Kevin Bates, and Rona Nichols. 2006. 'Still on the Books: Jim Crow and Segregation Laws Fifty Years after Brown v. Board of Education’. Michigan State Law Review 2006: 457-76.

Chubb, J E, and Terry M. Moe. 1990. Politics, Markets and America's Schools. Washington DC: The Brookings Institution.

Clotfelter, Charles T. 2004. After Brown: The Rise and Retreat of School Desegregation. Princeton and Oxford: Princeton University Press.

Coates, Ta-Nehisi. 2017. 'The First White President'. The Atlantic, October 2017. https://www.theatlantic.com/magazine/archive/2017/10/the-first-white-president-ta-nehisicoates/537909/.

Coles, Adrienne D. 1997. 'Poll Finds Growing Support for School Choice - Education Week'. 3 September 1997.

https://www.edweek.org/ew/articles/1997/09/03/01pdk.h17.html?qs=african+american+supp ort+vouchers+daterange:1981-07-01..2000-01-01.

Connolly, N.D.B. 2014. A World More Concrete: Real Estate and the Remaking of Jim Crow South Florida. Chicago and London: The University of Chicago Press.

Crespino, Joseph. 2007. In Search of Another Country: Mississippi and the Conservative Counterrevolution. Politics and Society in Twentieth-Century America. Princeton and Oxford: Princeton University Press.

Dorfman, Jeffrey. 2016. 'Teachers Unions, Faulty Economics, And School Choice'. Forbes, 13 November 2016. https://www.forbes.com/sites/jeffreydorfman/2016/11/13/teachers-unionsfaulty-economics-and-school-choice/\#f94e48d7c73f.

Douglas, Davison M. 2005. Jim Crow Moves North: The Battle over Northern School Segregation, 1865-1954. Cambridge Historical Studies in American Law and Society. Cambridge and New York: Cambridge University Press.

Eckes, Suzanne E., Julie Mead, and Jessica Ulm. 2016. 'Dollars to Discriminate: The (Un)Intended Consequences of School Vouchers'. Peabody Journal of Education 91 (4): 537-58. https://doi.org/10.1080/0161956X.2016.1207446.

EdChoice. 2018. 'School Choice in America Dashboard'. EdChoice. https://www.edchoice.org/school-choice/school-choice-in-america/.

Eggleston, Justice. 1959. Harrison v Day, 106 S.E.2d 636. Supreme Court of Appeals of Virginia. 
Feinstein, Brian D., and Eric Schickler. 2008. 'Platforms and Partners: The Civil Rights Realignment Reconsidered'. Studies in American Political Development 22 (1): 1-31. https://doi.org/10.1017/S0898588X08000011.

Ford, Chris, Stephenie Johnson, and Lisette Partelow. 2017. 'The Racist Origins of Private School Vouchers'. Center for American Progress.

https://www.americanprogress.org/issues/education/reports/2017/07/12/435629/racistorigins-private-school-vouchers/.

Forman, James. 2004. 'The Secret History of School Choice: How Progressives Got There First'. Georgetown Law Journal 93: 1287-1320.

. 2007. 'The Rise and Fall of School Vouchers: A Story of Religion, Race, and Politics'. UCLA L. Rev., Yale Law School Faculty Scholarship Series, 54: 547.

Francis, Megan Ming. 2014. Civil Rights and the Making of the Modern American State. New York: Cambridge University Press.

Frankenberg, Erica, and Genevieve Siegel-Hawley. 2010. 'Choosing Diversity: School Choice and Racial Integration in the Age of Obama'. Stanford Journal of Civil Rights \& Civil Liberties 6: 219-52.

Franzosi, Robert. 1987. 'The Press as a Source of Socio-Historical Data: Issues in the Methodology of Data Collection from Newspapers'. Historical Methods: A Journal of Quantitative and Interdisciplinary History 20 (1): 5-16.

Friedman, Milton. 1955. 'The Role of Government in Education'. In Economics and the Public Interest, edited by R.A. Solo. Rutgers University Press.

Frymer, Paul, and John David Skrentny. 1998. 'Coalition-Building and the Politics of Electoral Capture During the Nixon Administration: African Americans, Labor, Latinos’. Studies in American Political Development 12 (1): 131-61.

Garrett, Robert T. 2017. 'Texas House Passes Budget with Provision Banning School-Voucher Funding’. Dallas News, 7 April 2017. https://www.dallasnews.com/news/texaslegislature/2017/04/06/texas-house-fight-funding-ban-vouchers-social-issues-marathonbudget-wrangle.

Gilens, Martin. 1996. 'Race and Poverty in America: Public Misperceptions and the American News Media’. Public Opinion Quarterly 60 (4): 515-41. https://doi.org/10.1086/297771.

Gillion, Daniel Q. 2016. Governing with Words: The Political Dialogue on Race, Public Policy and Inequality in America. New York: Cambridge University Press.

Godbold, John Cooper, William Harold Cox, and Dan Monroe Russell. 1969. Coffey v. State Educational Finance Commission, 296 F.Supp 1389. US District Court for the Southern District of Mississippi.

Gooden, Mark A., Huriya Jabbar, and Jr. Mario S. Torres. 2016. 'Race and School Vouchers: Legal, Historical, and Political Contexts'. Peabody Journal of Education 91 (4): 522-36. https://doi.org/10.1080/0161956X.2016.1207445.

Hackett, Ursula. 2014. 'Republicans, Catholics and the West: Explaining the Strength of Religious School Aid Prohibitions’. Politics and Religion 7 (3): 499-520. . 2016. 'The Exit-Voice Choice: Religious Cleavages, Public Aid, and America’s Private Schools'. Politics and Religion 9 (2). https://doi.org/10.1017/S1755048316000201. . 2017a. 'Offers and Throffers: Education Policy under Obama'. In The Obama Presidency and the Politics of Change, by Edward Ashbee and John Dumbrell, 181-97. Studies of the Americas. New York: Palgrave Macmillan. . 2017b. 'Theorizing the Submerged State: The Politics of Private Schools in the United States'. Policy Studies Journal 45 (3): 464-89. https://doi.org/10.1111/psj.12170.

Hannah, John A., Eugene Patterson, Frankie Muse Freeman, Erwin N. Griswold, Theodore M. Hesburgh, and Robert S. Rankin. 1964. '1964 Staff Report: Public Education'. The United States Commission on Civil Rights. 
Harris, Fredrick. 2012. The Price of the Ticket. New York: Oxford University Press.

Harter, Jerome C., and Peter M. Hoffman. 1973. 'Segregation Academies and State Action'. The Yale Law Journal 82 (7): 1436-61.

Hess, Frederick M. 2004. Revolution at the Margins: The Impact of Competition on Urban School Systems. Washington DC: Brookings Institution Press.

Hill, David. 1998. 'Class Action - Education Week Teacher'. 1 April 1998. https://www.edweek.org/tm/articles/1998/04/01/07denver.h09.html?qs=african+american+su pport+vouchers+daterange:1981-07-01..2000-01-01.

Hochschild, Jennifer L. 1996. Facing Up to the American Dream. Princeton: Princeton University Press.

Infield, Tom. 2010. 'Pennsylvania Gubernatorial Candidates Advocate School-Vouchers Bill at Forum'. The Philadelphia Inquirer, 15 September 2010.

Johnson, Kimberley S. 2011. 'Racial Orders, Congress, and the Agricultural Welfare State, 18651940'. Studies in American Political Development 25 (02): 143-161. https://doi.org/10.1017/S0898588X11000095. . 2016. 'The Color Line and the State: Race and American Political Development'. In The Oxford Handbook of American Political Development, edited by Richard Valelly, Suzanne Mettler, and Robert Lieberman. Oxford Handbooks. Oxford: Oxford University Press.

Jones, James R. 2017. 'Serving Up Racism: Examining the Racial Order of Congressional Cafeterias’. Rutgers Univerity-Newark.

Katz, Bruce J., and Margery Austin Turner. 2001. 'Who Should Run the Housing Voucher Program? A Reform Proposal'. Housing Policy Debate 12 (2): 239-62. https://doi.org/10.1080/10511482.2001.9521403.

King, Alveda C. 1997. 'Fighting for School Choice. It's a Civil Right'. The Wall Street Journal, 11 September 1997.

King, Desmond. 2017. 'Forceful Federalism against American Racial Inequality'. Government and Opposition 52 (02): 356-82. https://doi.org/10.1017/gov.2016.52.

King, Desmond, and Rogers M. Smith. 2005. 'Racial Orders in American Political Development'. American Political Science Review 99 (1): 75-92.

. 2011. Still a House Divided. Princeton Studies in American Politics: Historical, Institutional, and Comparative Perspectives. Princeton and Oxford: Princeton University Press.

. 2014. "Without Regard to Race”: Critical Ideational Development in Modern American Politics'. The Journal of Politics 76 (4): 958-71. https://doi.org/10.1017/S0022381614000541. . 2016. 'The Last Stand?: Shelby County v. Holder $</$ span>, White Political Power, and America’s Racial Policy Alliances'. Du Bois Review: Social Science Research on Race 13 (1): 25-44. https://doi.org/10.1017/S1742058X1500017X.

Knoll, Erwin. 1960. 'Virginia Board Revises Tuition Distribution'. The Washington Post, Times Herald, 3 August 1960.

Kruse, Kevin M. 2005. White Flight: Atlanta and the Making of Modern Conservatism. Princeton, New Jersey: Princeton University Press.

Ladson-Billings, Gloria. 2004. 'Landing on the Wrong Note: The Price We Paid for Brown'. Educational Researcher 33 (7): 3-13.

Lawton, Millicent. 1992. 'Gallup Poll Finds Wide Support for Tuition Vouchers - Education Week'. 23 September 1992. https://www.edweek.org/ew/articles/1992/09/23/033cho.h12.html?qs=african+american+support+vouchers.

Leal, David L. 2004. 'Latinos and School Vouchers: Testing the “Minority Support” Hypothesis'. Social Science Quarterly 85 (5): 1227-37. 
Levitz, Eric. 2017. 'Devos Champions HBCUs As Pioneers of “School Choice”'. The New York Magazine, 28 February 2017. http://nymag.com/daily/intelligencer/2017/02/devoschampions-hbcus-as-pioneers-of-school-choice.html?mid=full-rss-di.

Lieberman, Robert C. 1997. Shifting the Color Line. Cambridge MA: Harvard University Press. Lowndes, Joseph, Jule Novkov, and Warren, eds. 2008. Race and American Political Development. New York: Routledge.

MacLean, Nancy. 2017. Democracy in Chains: The Deep History of the Radical Right's Stealth Plan for America. Melbourne and London: Scribe Publications.

Marley, Patrick. 2013. 'Past School Voucher Advocate Rips Gov. Walker’s Plan'. The Wisconsin Journal Sentinel, 16 May 2013.

Marley, Patrick, and Jason Stein. 2011. 'Walker: Budget Could Expand School Choice to Other Cities’. The Wisconsin Journal Sentinel, 10 May 2011.

Mazumder, Soumyajit. 2018. 'The Persistent Effect of US Civil Rights Protests on Political Attitudes'. American Journal of Political Science.

McBee, Susanna. 1963. 'Report Shows South’s Fight to Keep Schools Segregated Has Been Costly'. The Washington Post, Times Herald, 14 July 1963.

McCarty, Nolan, Keith T. Poole, and Howard Rosenthal. 2016. Polarized America: The Dance of Ideology and Unequal Riches. Cambridge MA: MIT Press.

Mettler, Suzanne. 2009. The Submerged State: How Invisible Government Policies Undermine American Democracy. Chicago: University of Chicago Press.

Mickey, Robert. 2015. Paths Out of Dixie. Princeton: Princeton University Press.

Minow, Martha. 2010. In Brown's Wake: Legacies of America's Educational Landmark. Oxford: Oxford University Press.

Murakawa, Naomi. 2014. The First Civil Right. New York: Oxford University Press.

Muse, Benjamin. 1961. Virginia's Massive Resistance. Bloomington, IN: Indiana University Press.

- 1964. Ten Years of Prelude: The Story of Integration since the Supreme Court's 1954 Decision. Beaconsfield: Darwen Finlayson.

O’Brien, Molly T. 1996. 'Private School Tuition Vouchers and the Realities of Racial Politics'. Tennessee Law Review 64: 359-408.

Peltason, Jack Walter. 1971. Fifty-Eight Lonely Men: Southern Federal Judges and School Desegregation. Urbana: University of Illinois Press.

Persson, Jonas. 2015. 'Vouchers on the Move: Return to School Segregation?' The Cnter for Media and Democracy's PR Watch, 28 April 2015. http://www.prwatch.org/news/2015/02/12730/segregation-school-vouchers.

Pilarczyk, Daniel Edward. Letter to George Voinovich. 1991. 'Pilarczyk to Voinovich', 3 July 1991. Box, GVV, 47, ED:AD-ED:GEM. Folder, Education Choice Committee. Voinovich Archives.

- Letter to George Voinovich. 1993. 'Pilarczyk to Voinovich', 27 August 1993. Box, GVV, 47, ED:AD-ED:GEM. Folder, Education Choice Committee. Voinovich Archives.

Potter, Halley. 2017. 'Do Private School Vouchers Pose a Threat to Integration?' The Century Foundation: Report - School Integration. https://s3-us-west-

2.amazonaws.com/production.tcf.org/app/uploads/2017/03/22102646/do-private-schoolvouchers-pose-a-threat-to-integration.pdf.

Prothero, Arianna. 2014. 'Q\&A With Howard Fuller on “The Mother of School Choice,” Annette Polly Williams’. Education Week - Charters \& Choice. 21 November 2014.

http://blogs.edweek.org/edweek/charterschoice/2014/11/qa_with_howard_fuller_on_the_mot her_of_school_choice_annette_polly_williams.html?cmp=SOC-SHR-FB.

Ravitch, Diane. 2001. 'The Right Thing: Why Liberals Should Be Pro-Choice'. Brookings Institution Press. https://www.brookings.edu/articles/the-right-thing-why-liberals-should-be-pro-choice/. 
2013. Reign of Error: The Hoax of the Privatization Movement and the Danger to America's Public Schools. New York: Knopf Publishing Group.

Ravitch, J. 2014. 'Vouchers Undermine Public Education System'. Chapel Hill News, 14 March 2014.

Reardon, Sean F., and John T. Yun. 2002. 'Private School Racial Enrollments and Segregation'. The Civil Rights Project, Harvard University, June.

Rehnquist, William. 2002. Zelman v Simmons-Harris, 536 U.S. 639. U.S. Supreme Court.

Reid, Karla Scoon. 2001a. 'Poll Finds Support for Vouchers Wanes If Public Schools Affected Education Week'. 3 October 2001.

https://www.edweek.org/ew/articles/2001/10/03/05nsba.h21.html?qs=african+american+supp ort+vouchers.

. 2001b. 'Minority Parents Quietly Embrace School Choice - Education Week'. Education Week, 5 December 2001.

https://www.edweek.org/ew/articles/2001/12/05/14introminority.h21.html?qs=african+ameri can+support+vouchers.

Resmovits, Joy. 2017. 'Betsy DeVos Would Not Agree to Bar Discrimination by Private Schools That Get Federal Money’. Los Angeles Times, 24 May 2017.

Rives, Richard Taylor, Harlan Hobart Grooms, and Frank Minis Johnson. 1964. Lee v. Macon County Board of Education, 231 F.Supp 743. United States District Court M. D. Alabama, E. D.

Rodriguez, Zeus. 2011. 'School Choice Students Are Not Pawns'. The Wisconsin Journal Sentinel, 27 January 2011.

Ruenzel, David. 1995. 'A Choice in The Matter - Education Week’. 7 September 1995. https://www.edweek.org/ew/articles/1995/09/07/04milwau.h15.html?qs=african+american+v ouchers+segregation+polly+daterange:1988-01-01..2000-01-01.

Samson, Frank L. 2012. 'Perceptions of Racialized Opportunities and Hispanics’ Political Attitudes: Predicting Support for School Vouchers and Government Intervention in Health Care'. American Behavioral Scientist 56 (11): 1525-64. https://doi.org/10.1177/0002764212458278.

Schickler, Eric. 2016. Racial Realignment: The Transformation of American Liberalism, 1932-1965. Princeton, New Jersey: Princeton University Press.

Schickler, Eric, and Ruth Bloch Rubin. 2016. 'Congress and American Political Development'. In The Oxford Handbook of American Political Development. Oxford University Press.

Skowronek, Stephen, and Karen Orren. 2016. 'Pathways to the Present: Political Development in America'. In The Oxford Handbook of American Political Development, edited by Richard Valelly, Suzanne Mettler, and Robert Lieberman, 27-47. Oxford Handbooks. Oxford: Oxford University Press.

Snow, McKenzie. 2016. 'School Choice: “The Civil Rights Issue of Our Time”'. Excel in Ed, 4 February 2016.

Special to the New York Times. 1959. 'State Tuition Aid Urged by Faubus'. New York Times, 10 February 1959.

. 1961. 'Faubus Proposes Integration Bar'. New York Times, 22 January 1961.

1964. 'Mississippi Faces New School Step’. New York Times, 10 August 1964.

. 1967. 'Maddox Is Rebutted on Private Pupils'. New York Times, 28 August 1967.

Tausanovitch, C, and C Warshaw. 2013. 'Measuring Constituent Policy Preferences in Congress, State Legislatures, and Cities'. The Journal of Politics 75 (2): 330-42.

Tenbrink, Trevor. 2013. 'Superintendent's Shocking Comment Reminds Us That School Choice Is an Uphill Battle’. Education Action Group News, 9 April 2013.

Tesler, Michael. 2012. 'The Spillover of Racialization into Health Care: How President Obama Polarized Public Opinion by Racial Attitudes and Race'. American Journal of Political Science 56 (3): 690-704. 
2016. Post-Racial or Most-Racial?: Race and Politics in the Obama Era. Chicago: University of Chicago Press.

Thurston, Chloe N. 2015. 'Policy Feedback in the Public-Private Welfare State: Advocacy Groups and Access to Government Homeownership Programs, 1934-1954’. Studies in American Political Development 29 (02): 250-267. https://doi.org/10.1017/S0898588X15000097.

Ujifusa, Andrew. 2017. 'Ed. Dept. Has No Plans for a “Federal Voucher Program.” Let’s Break That Down.’ Education Week - Politics K-12, 31 May 2017. http://blogs.edweek.org/edweek/campaign-k12/2017/05/federal_voucher_program_no_plans_education_department.html?cmp=SOCSHR-FB.

Valentino, Nicholas A., Vincent L. Hutchings, and Ismail K. White. 2002. 'Cues That Matter: How Political Ads Prime Racial Attitudes During Campaigns'. American Political Science Review 96 (1): 75-90. https://doi.org/10.1017/S0003055402004240.

Voinovich, George. Letter to Daniel Edward Pilarczyk. 1991. 'Voinovich to Pilarczyk', 14 June 1991. Box, GVV, 42, CAP-CH1. Catholic Diocese - Pilarczyk, Dan Archbishop. Voinovich Archives.

Walsh, Mark. 2013. 'Louisiana Vouchers, Desegregation Case Prove Volatile Mix - Education Week'. Education Week, 18 September 2013. https://www.edweek.org/ew/articles/2013/09/18/04louisiana-2.h33.html.

Wearne, Eric. 2013. 'From "Fear-Based” Choice to "Freedom-Based” Choice: Georgia’s Tuition Grants Act, 1960-1997’. Journal of School Choice 7: 196-224.

Wisdom, Justice. 1961. Hall v. St. Helena Parish School Board, 197 F.Supp 649. U.S. District Court for the Eastern District of Louisiana. . 1968. Poindexter v. Louisiana Financial Assistance Commission, 275 F.Supp. 833. U.S. District Court for the Eastern District of Louisiana.

Worden, Amy, and Dan Hardy. 2011. 'Corbett Appears Set to Push School Vouchers'. The Philadelphia Inquirer, 20 January 2011.

Young, Richard P., and Jerome S. Burstein. 1995. 'Federalism and the Demise of Prescriptive Racism in the United States'. Studies in American Political Development 9 (1): 1-54. https://doi.org/10.1017/S0898588X00001164.

Zelman v Simmons-Harris. 2002, 536 U.S. 639. The Supreme Court of the United States. 
Tables

\begin{tabular}{|c|c|c|c|}
\hline & Color-blind & Race-conscious & $\begin{array}{c}\text { In King and Smith } \\
\text { (italics added) }\end{array}$ \\
\hline $\begin{array}{l}\text { Framing } \\
\text { and } \\
\text { rhetoric }\end{array}$ & $\begin{array}{l}\text { No mention of race in } \\
\text { policy wording, discussion } \\
\text { points or amongst elites } \\
\text { during bill passage. } \\
\text { Example: Disavowal of } \\
\text { racial categories in GOP } \\
\text { party platform }\end{array}$ & $\begin{array}{l}\text { Legislation mentions race, } \\
\text { or policy is framed in } \\
\text { racial terms during bill } \\
\text { passage. } \\
\text { Example: Direct } \\
\text { acknowledgment of racial } \\
\text { groups in Democratic } \\
\text { party platform }\end{array}$ & $\begin{array}{c}\text { 'This framing of racial } \\
\text { issues has produced a } \\
\text { polarized politics of } \\
\text { disputatious mutual } \\
\text { disrespect...' (D. King and } \\
\text { Smith 2011, 12) } \\
\text { ‘...the party has professed } \\
\text { commitments to color- } \\
\text { blind policy approaches...' } \\
\text { (D. King and Smith 2011, } \\
\text { 10) }\end{array}$ \\
\hline $\begin{array}{l}\text { Policy } \\
\text { design and } \\
\text { targets }\end{array}$ & $\begin{array}{l}\text { Policy does not target } \\
\text { particular racial groups; } \\
\text { individual based market- } \\
\text { oriented mechanisms. } \\
\text { Example: Tax } \\
\text { expenditures }\end{array}$ & $\begin{array}{c}\text { Direct state action to } \\
\text { ameliorate racial } \\
\text { inequalities; policy targets } \\
\text { particular racial categories. } \\
\text { Example: Affirmative } \\
\text { action programs }\end{array}$ & $\begin{array}{l}\text { 'Proponents of both color- } \\
\text { blind and race-conscious } \\
\text { policies have drawn the } \\
\text { wrong lesson from this } \\
\text { history.' (D. King and } \\
\text { Smith 2011, 11) } \\
\text { 'Measures...designed and } \\
\text { implemented with specific } \\
\text { goals of racial equality in } \\
\text { view' (D. King and Smith } \\
\text { 2011, 9) }\end{array}$ \\
\hline $\begin{array}{l}\text { Patterns of } \\
\text { support }\end{array}$ & $\begin{array}{l}\text { Support drawn from } \\
\text { conservatives and } \\
\text { Republicans: color-blind } \\
\text { alliance. }\end{array}$ & $\begin{array}{l}\text { Support drawn from } \\
\text { liberals and Democrats: } \\
\text { race-conscious alliance. }\end{array}$ & $\begin{array}{l}\text { 'Race-conscious } \\
\text { proponents' and 'color- } \\
\text { blind advocates' } \\
\text { The 'clash of rival “color- } \\
\text { blind” and "race- } \\
\text { conscious” racial policy } \\
\text { alliances' (D. King and } \\
\text { Smith 2011,9) }\end{array}$ \\
\hline
\end{tabular}




\begin{tabular}{|c|c|c|c|}
\hline \multicolumn{4}{|c|}{ Table 2: Three Eras of Voucher Politics } \\
\hline Era & $\begin{array}{c}\text { Jim Crow and the } \\
\text { aftermath of } \\
\text { Brown (1950- } \\
1964)\end{array}$ & $\begin{array}{c}\text { Era of Transition } \\
(1964-96)\end{array}$ & $\begin{array}{c}\text { The Civil Rights Era } \\
\text { and Rise of Color Blind } \\
\text { Vouchers } \\
(1996-)\end{array}$ \\
\hline $\begin{array}{l}\text { Patterns } \\
\text { of } \\
\text { support }\end{array}$ & White supremacists & $\begin{array}{c}\text { Scattered liberal support; } \\
\text { race-conscious } \\
\text { opposition and strange } \\
\text { bedfellow alliances }\end{array}$ & Color-blind alliance \\
\hline $\begin{array}{l}\text { Framing } \\
\text { and } \\
\text { rhetoric }\end{array}$ & $\begin{array}{l}\text { Veneer of color- } \\
\text { blindness: } \\
\text { 'freedom of } \\
\text { association' }\end{array}$ & $\begin{array}{l}\text { Liberal vs segregationist } \\
\text { versions; some race- } \\
\text { conscious arguments }\end{array}$ & $\begin{array}{c}\text { Smorgasbord of } \\
\text { arguments, but } \\
\text { dominated by color- } \\
\text { blind frames }\end{array}$ \\
\hline $\begin{array}{l}\text { Design } \\
\text { and } \\
\text { targets }\end{array}$ & $\begin{array}{c}\text { Quasi-direct } \\
\text { transfers of public } \\
\text { funds; } \\
\text { decentralized } \\
\text { administration; } \\
\text { targeted at whites }\end{array}$ & $\begin{array}{l}\text { Mixture of tuition aid } \\
\text { and in-kind aid } \\
\text { programs; some indirect } \\
\text { transfer of voucher funds } \\
\text { via parents; some race } \\
\text { targeting }\end{array}$ & $\begin{array}{l}\text { Increasingly indirect } \\
\text { transfers; tax credit } \\
\text { funding; target } \\
\text { dependent upon program } \\
\text { design }\end{array}$ \\
\hline
\end{tabular}




\begin{tabular}{|c|c|c|}
\hline \multicolumn{3}{|c|}{ Table 3: Vouchers in the Era of Segregation. } \\
\hline $\begin{array}{c}\text { Four } \\
\text { approaches }\end{array}$ & Characteristics & States \\
\hline $\begin{array}{l}\text { Massive } \\
\text { resistance }\end{array}$ & $\begin{array}{c}\text { Early adopters of tuition grants alongside an } \\
\text { all-out assault on the Brown ruling: school } \\
\text { closures, abolition of compulsory attendance, } \\
\text { interposition etc. }\end{array}$ & $\begin{array}{l}\text { Virginia, Louisiana, } \\
\text { Georgia, Alabama }\end{array}$ \\
\hline Safety valve & $\begin{array}{c}\text { Adoption but no actual distribution of public } \\
\text { tuition grants. An effort to strike a balance } \\
\text { between placating segregationists and } \\
\text { avoiding legal challenge }\end{array}$ & $\begin{array}{l}\text { North Carolina, } \\
\text { Arkansas }\end{array}$ \\
\hline Resignation & $\begin{array}{l}\text { No tuition grant legislation. Slow and } \\
\text { unenthusiastic but steady progress towards } \\
\text { desegregating the public schools }\end{array}$ & $\begin{array}{c}\text { Maryland, West } \\
\text { Virginia, Kentucky, } \\
\text { Tennessee }\end{array}$ \\
\hline $\begin{array}{c}\text { Violent } \\
\text { suppression }\end{array}$ & $\begin{array}{l}\text { Tuition grant legislation not needed at first } \\
\text { because fear of violent reprisals stifles the } \\
\text { prospect of legal challenge. Much later } \\
\text { adopters of tuition grants, after barriers to } \\
\text { desegregation finally start to fall }\end{array}$ & $\begin{array}{l}\text { Mississippi, South } \\
\text { Carolina }\end{array}$ \\
\hline
\end{tabular}


Table 4: Racial characteristics of Milwaukee and Cleveland’s populations, 1990

\begin{tabular}{|l|l|l|l|l|}
\hline & White & African-American & Other & Total \\
\hline Milwaukee & $398,033(63 \%)$ & $191,255(30 \%)$ & $38,800(6 \%)$ & 628,088 \\
\hline Wisconsin* & $4,512,523(92 \%)$ & $244,539(5 \%)$ & $134,707(3 \%)$ & $4,891,769$ \\
\hline Cleveland & $250,234(49 \%)$ & $235,405(47 \%)$ & $19,977(4 \%)$ & 505,616 \\
\hline Ohio* & $9,521,756(88 \%)$ & $1,154,826(11 \%)$ & $170,533(2 \%)$ & $10,847,115$ \\
\hline
\end{tabular}

*State as a whole. Source: U.S. Census 1990 


\begin{tabular}{|c|c|c|c|c|c|c|}
\hline $\begin{array}{l}\text { Partisan } \\
\text { affiliation }(\mathrm{R}=1)\end{array}$ & $\begin{array}{l}1.268 * * * \\
(.366)\end{array}$ & $\begin{array}{l}1.335^{* * *} \\
(.351)\end{array}$ & $\begin{array}{l}1.329 * * * \\
(.355)\end{array}$ & $\begin{array}{l}1.209 * * * \\
(.338)\end{array}$ & $\begin{array}{l}1.217 * * * \\
(.337)\end{array}$ & $\begin{array}{l}1.213^{* * *} \\
(.339)\end{array}$ \\
\hline Sex $($ Male $=1)$ & & $-.562(.351)$ & $-.579(.367)$ & $.394(.300)$ & $.394(.301)$ & $.375(.373)$ \\
\hline Race (White = 1) & & & $.204(.507)$ & $.709(.498)$ & $.715(.498)$ & $.800(.526)$ \\
\hline Date of challenge & & & & $.061 * * *(.010)$ & $.060 * * *(.010)$ & $.080 * * *(.014)$ \\
\hline No Aid Provision & & & & & $.033(.091)$ & $.080(.096)$ \\
\hline Region North & & & & & & $.543(.871)$ \\
\hline Midwest & & & & & & $\begin{array}{l}1.217 * * * \\
(.459)\end{array}$ \\
\hline West & & & & & & $-.867 * *(.509)$ \\
\hline Constant & $\begin{array}{l}-1.248^{* * *} \\
(.325)\end{array}$ & $-.807 *(.477)$ & $-.982 * *(.484)$ & $\begin{array}{l}-123.751^{* * *} \\
(20.588)\end{array}$ & $\begin{array}{l}-121.969 * * * \\
(20.212)\end{array}$ & $\begin{array}{l}-163.144^{* * *} \\
(28.729)\end{array}$ \\
\hline
\end{tabular}




\begin{tabular}{|c|c|c|}
\hline \multicolumn{3}{|c|}{$\begin{array}{l}\text { Table 6: State legislator votes on successful and unsuccessful voucher bill votes held } \\
\text { 2005-2017. Multilevel logistic regression with robust standard errors clustered by } \\
\text { state }\end{array}$} \\
\hline \multicolumn{3}{|c|}{ Individual and district level variables } \\
\hline & Main effects model & Interactive model \\
\hline Partisan affiliation $($ Republican $=1)$ & $4.782 * * *(.232)$ & $5.553 * * *(.273)$ \\
\hline District ideology & $.735 * * *(.278)$ & $1.468 * * *(.350)$ \\
\hline Partisan affiliation*district ideology & & $-1.027 * * *(.466)$ \\
\hline \% Government employees in district & $-3.267 * *(1.260)$ & $-2.760 * *(1.230)$ \\
\hline Legislator race $($ Black $=1)$ & $-.398 *(.220)$ & $-.696 * * *(.222)$ \\
\hline Legislator sex $($ Male $=1)$ & $.295 * *(.131)$ & $.262 * *(.130)$ \\
\hline \% African-Americans in district & $.020 * * *(.005)$ & $.030 * * *(.006)$ \\
\hline $\begin{array}{l}\text { Partisan affiliation*\% African- } \\
\text { Americans in district }\end{array}$ & & $-.069 * * *(.009)$ \\
\hline \% Private school enrollment & $-.017 * * *(.003)$ & $.020 * * *(.003)$ \\
\hline \multicolumn{3}{|l|}{ State level variables } \\
\hline State educational expenditure & $-.187 * * *(.069)$ & $-.186 * *(.073)$ \\
\hline Previous legal challenge & $.304(.659)$ & $-.409(.684)$ \\
\hline \% Unionization & $-.207 * * *(.060)$ & $-.217 * * *(.061)$ \\
\hline Constant & $7.245 * * *(2.790)$ & $7.096 * *(2.954)$ \\
\hline
\end{tabular}


Figures

Figure 1: The renaissance of vouchers - cumulative total of voucher programs in the United States, 1945-2016

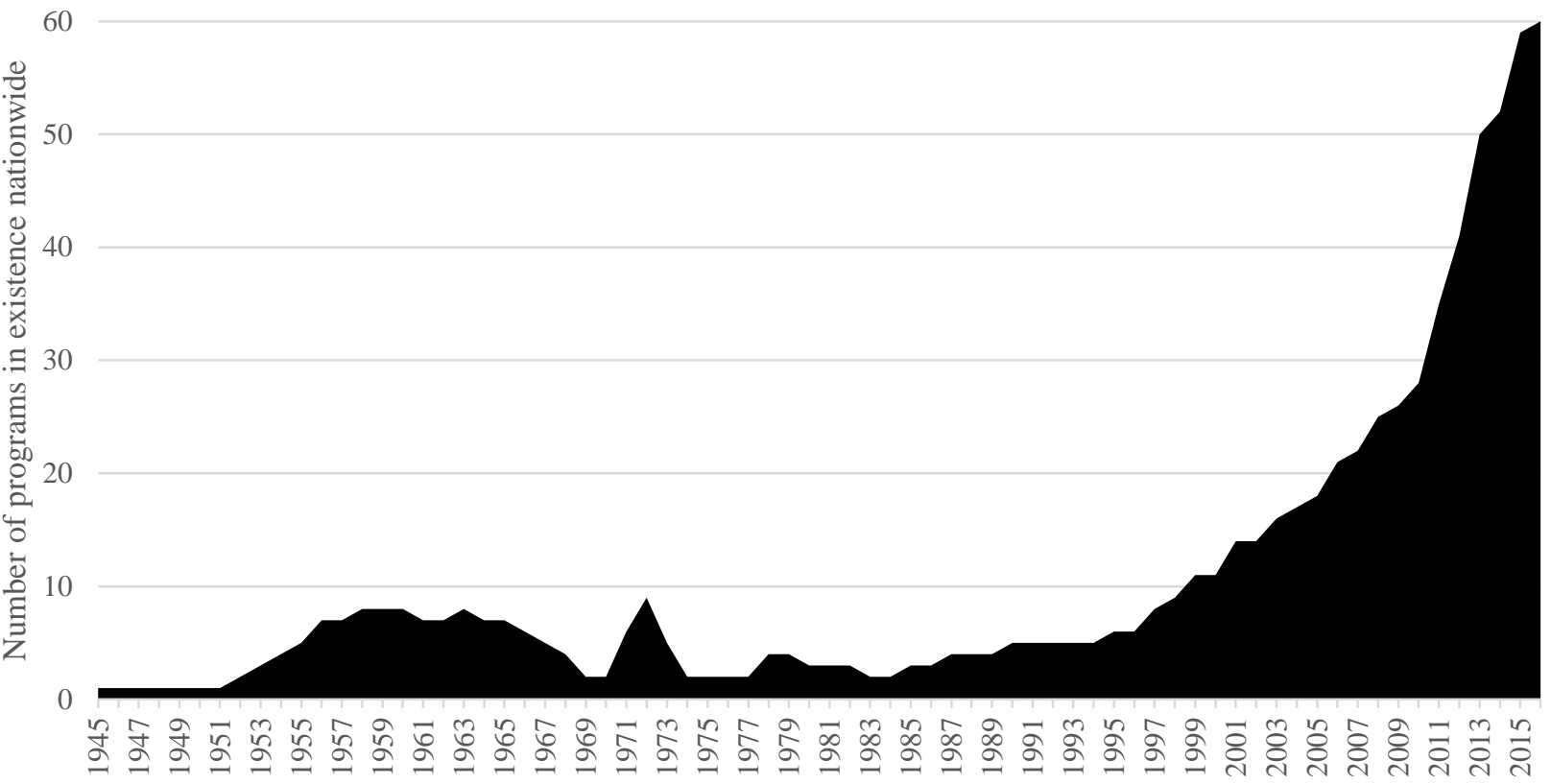


Figure 2: Selected southern states' issuance of vouchers in the era of segregation.

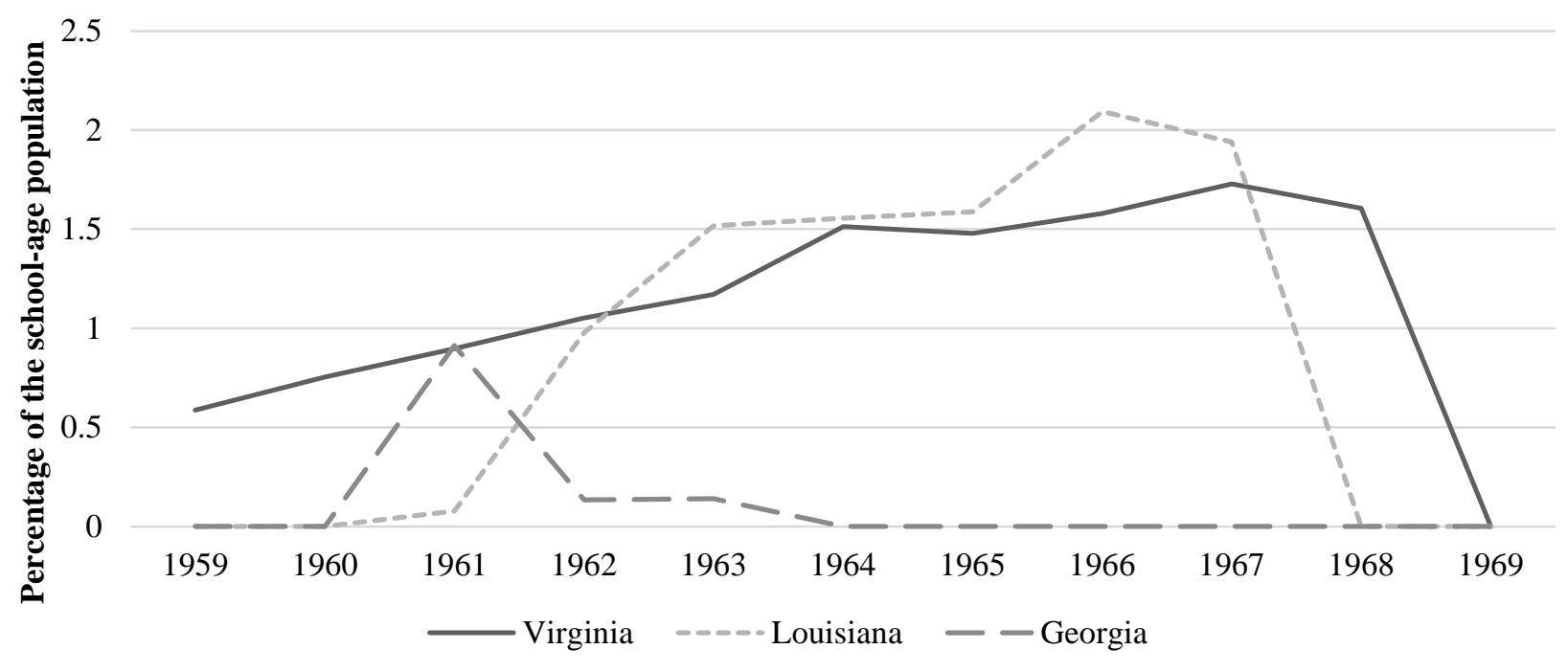


Figure 3: Enrollment in the Milwaukee and Cleveland voucher programs as a proportion of the 5-18 year old population in each city

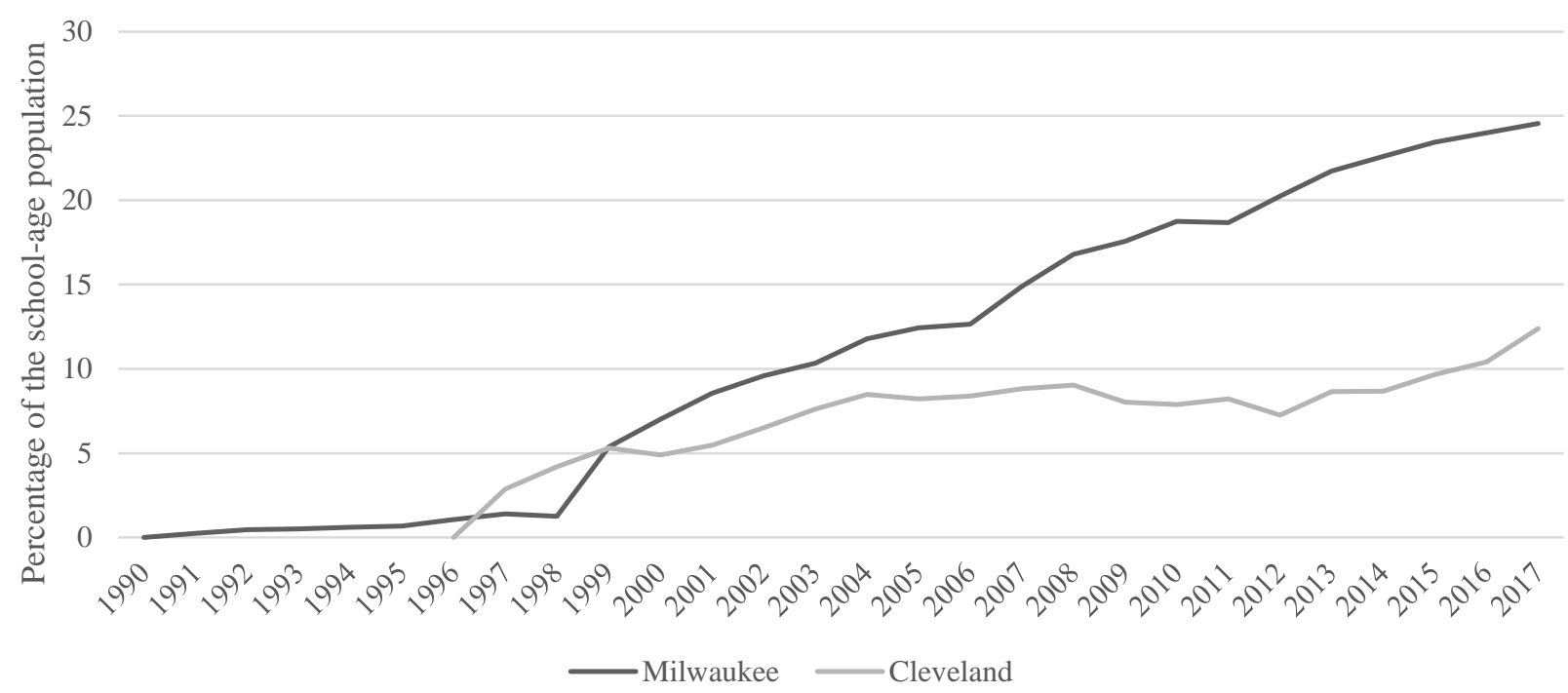

Sources: Wisconsin Department of Public Instruction; Ohio Department of Education; EdChoice.org; US Census Bureau (2010) 
Figure 4: Enrollments in voucher programs as a proportion of 5-19 year olds in selected states, 2005-2015

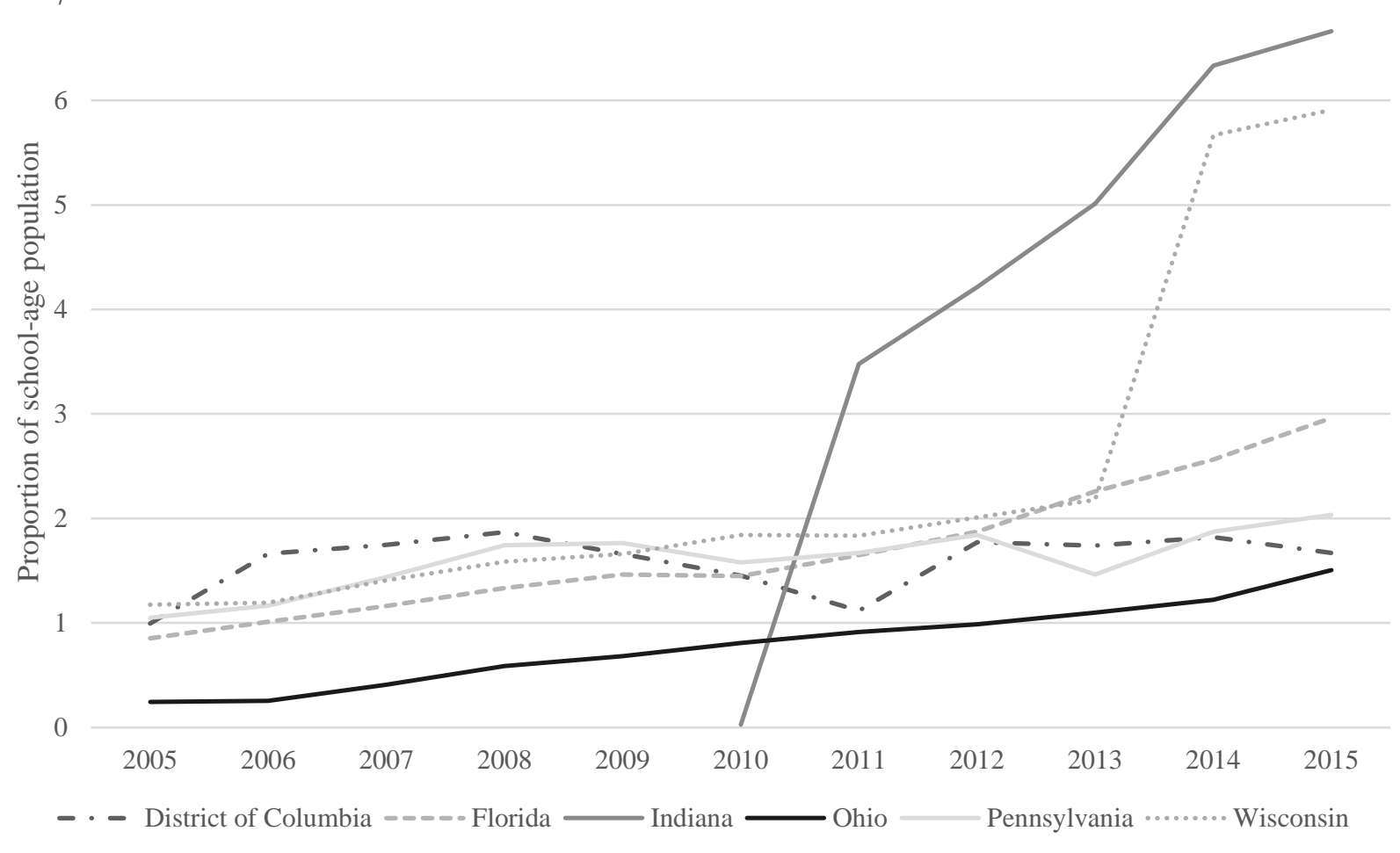


Figure 5: Interaction between partisanship and district ideology

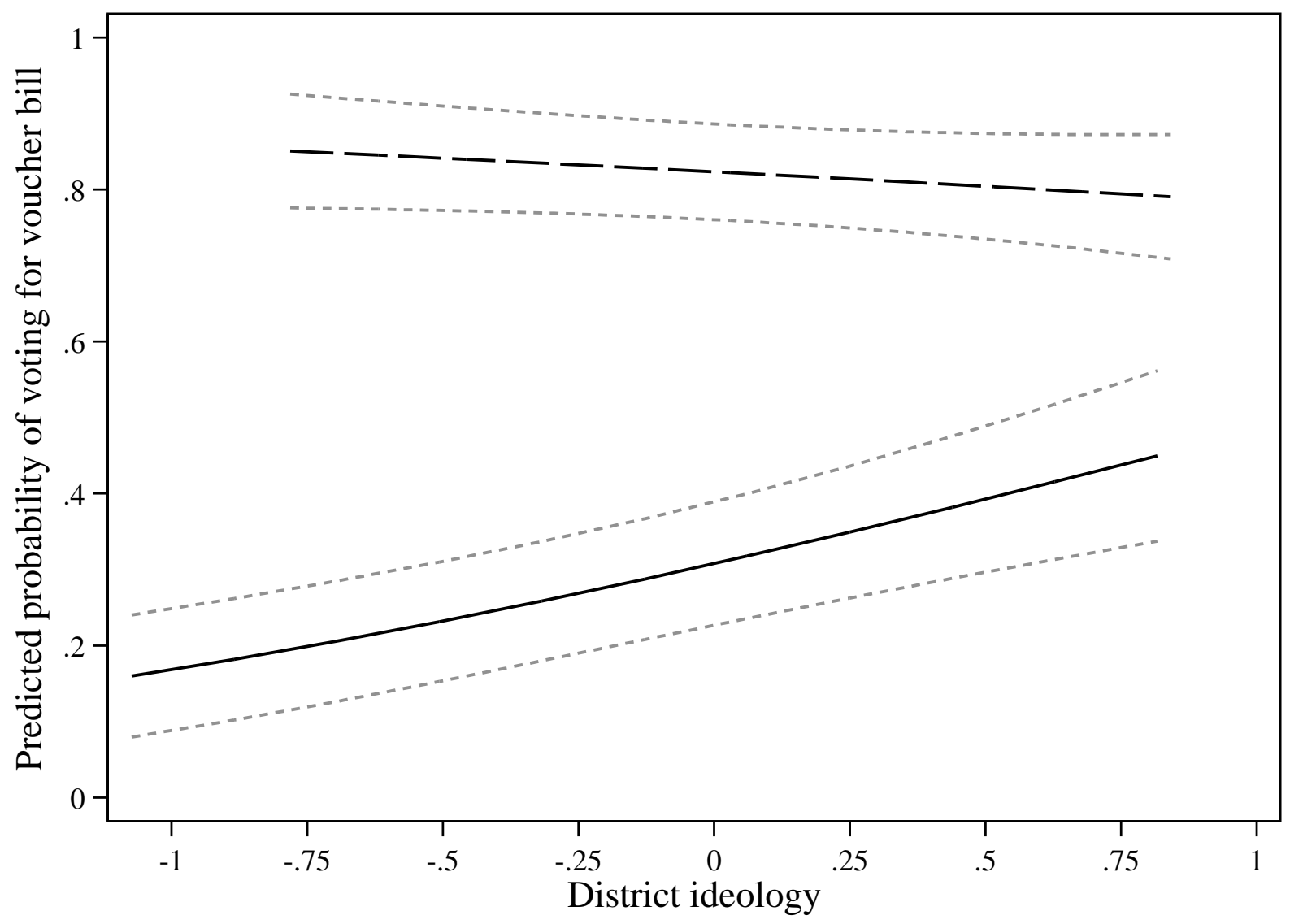

Democrat - - Republican 
Figure 6: Interaction between legislator partisanship and racial district characteristics

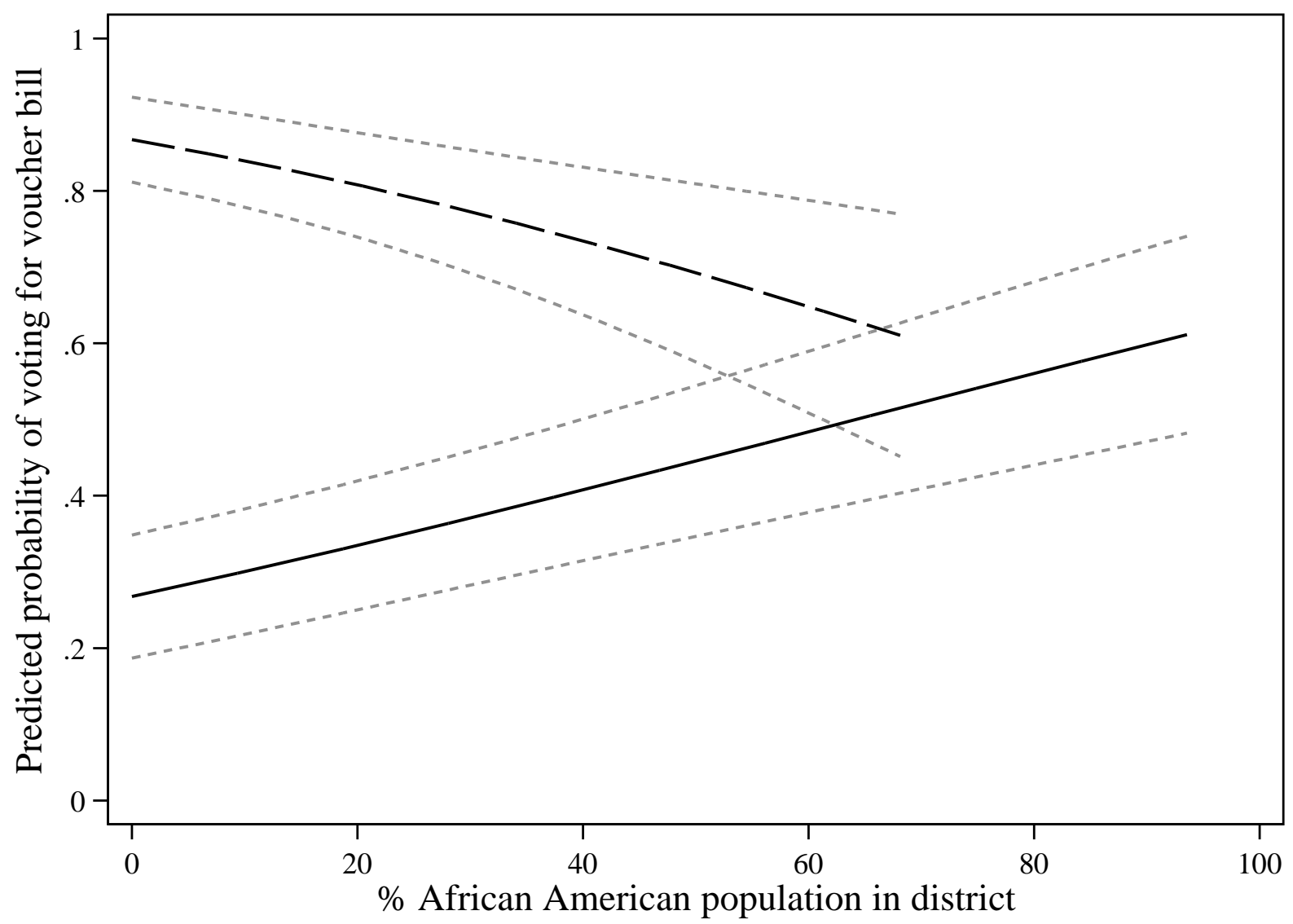

Democrat - - Republican 